This PDF is a selection from a published volume from the National Bureau of Economic Research

Volume Title: Commodity Prices and Markets, East Asia Seminar on Economics, Volume 20

Volume Author/Editor: Takatoshi Ito and Andrew K. Rose, editors

Volume Publisher: University of Chicago Press

Volume ISBN: 0-226-38689-9

ISBN13: 978-0-226-38689-8

Volume URL: http://www.nber.org/books/ito_09-1

Conference Date: June 26-27, 2009

Publication Date: February 2011

Chapter Title: The Effects of Oil Price Changes on the Industry-Level Production and Prices in the United States and Japan

Chapter Authors: Ichiro Fukunaga, Naohisa Hirakata, Nao Sudo Chapter URL: http://www.nber.org/chapters/c11874

Chapter pages in book: (195 - 231) 


\title{
The Effects of Oil Price Changes on the Industry-Level Production and Prices in the United States and Japan
}

\author{
Ichiro Fukunaga, Naohisa Hirakata, and Nao Sudo
}

\subsection{Introduction}

There is a large body of empirical literature on the effects of oil price changes on the U.S. economy; their magnitudes, transmission mechanisms, and historical changes have been investigated. However, the underlying causes of oil price changes have not been seriously considered until recently. The way oil price changes affect the economy may be very different depending on where the changes fundamentally come from. In particular, global factors such as rapid growth in emerging economies and the integration of global supply chains seem to have become increasingly important for oil price changes themselves and their transmission mechanisms.

Moreover, much remains unknown about the effects of oil price changes in countries other than the United States. Some recent empirical international comparative studies show that the magnitudes of the effects of oil price changes differ greatly even among oil-importing countries. In particular, Japan is different in the sense that oil price increases have little, or even a positive, effect on real economic activity. ${ }^{1}$

Ichiro Fukunaga is director of the Research and Statistics Department at the Bank of Japan. Naohisa Hirakata is deputy director of the Research and Statistics Department at the Bank of Japan. Nao Sudo is deputy director of the Institute for Monetary and Economic Studies at the Bank of Japan.

This chapter was prepared for the 20th Annual East Asia Seminar on Economics, Hong Kong, June 26-27, 2009. The authors are grateful to their discussants, Francis Lui and Warwick McKibbin, the organizers, Takatoshi Ito and Andrew Rose, and other participants for helpful comments and discussions. The authors would also like to thank seminar participants at the Institute for Monetary and Economic Studies, Bank of Japan. Views expressed in this chapter are those of the authors and do not necessarily reflect those of the Bank of Japan.

1. Recent studies, including those of Blanchard and Galí (2007) and Jiménez-Rodríguez and Sánchez (2004), show that the effects of oil price changes in Japan are exceptionally different from other oil-importing countries. 
In this chapter, we investigate the underlying causes of oil price changes and their transmission mechanisms in the United States and Japan. We decompose oil price changes into their component parts and estimate the dynamic effects of each component on industry-level production and prices in both countries using identified vector autoregression (VAR) models. Our models incorporate two major extensions to the standard models used in previous studies. First, instead of treating oil price changes as exogenous shocks, we identify the underlying demand and supply shocks to the global oil market. Second, we use industry-level data as well as aggregate data to investigate the transmission mechanisms of oil price changes in more detail. $^{2}$ Our models have three-block structures comprising the global oil market block, the domestic macroeconomy block, and the domestic industry block. To our knowledge, this is the first attempt to investigate the effects of structural shocks to the global oil market on industry-level production and prices. ${ }^{3}$

In identifying structural shocks to the global oil market, we closely follow Kilian (2009), who proposes a structural decomposition of the real price of oil into the following three components: oil supply shocks; shocks to the global demand for all industrial commodities (global demand shocks); ${ }^{4}$ and demand shocks that are specific to the global oil market (oil-specific demand shocks). These three structural shocks that all tend to raise the oil price have very different effects on domestic economic activity. While an unexpected disruption of oil supply and an unexpected increase in oil-specific demand tend to reduce domestic industrial production, an unexpected increase in global demand raises domestic production. One of the main reasons why the surge in oil prices from 2002 seems to have had a smaller effect on real economic activity than did the oil price increases of the 1970s is that the recent oil price surge and economic expansion were simultaneously driven by the global demand shocks. ${ }^{5}$

Examining the industry-level effects of oil price changes facilitates under-

2. We focus on manufacturing industries for which lengthy periods of monthly time-series data are available. The quarterly gross domestic product (GDP) data that include nonmanufacturing industries are not compatible with the short-run restrictions on our structural VAR models.

3. Kilian and Park (2009) briefly analyze the effects of structural shocks to the global oil market on industry-level stock returns using a two-block VAR model.

4. Kilian (2009) refers to this component as an "aggregate demand shock." We do not use this term because it can be confused with domestic aggregate shocks in our model.

5. Blanchard and Galí (2007) offer other explanations for the smaller effects: the smaller share of oil in production, greater labor market flexibility, and improvements in monetary policy. Rather than consider these structural changes, we focus on changes in the nature of the shocks to the global oil market. As mentioned in the appendix, estimating our models for shorter sample periods does not greatly change most of the impulse responses to the identified shocks, except those to the oil supply shocks. Hirakata and Sudo (2009) point out that reduced oil supply variation and the associated correlation with total factor productivity may be more important than structural changes for explaining the smaller effects of oil price changes on real economic activity. 
standing of their transmission mechanisms. Lee and Ni (2002) estimate the effects of exogenous oil price shocks using U.S. industry-level data and find that oil price shocks act mainly as supply shocks for oil-intensive industries - such as petroleum refineries - and act mainly as demand shocks for many other industries. ${ }^{6}$ They distinguish between demand and supply shocks depending on whether production and prices move in the same or opposite directions in response to the shocks. Our estimation results for the domestic industry block reveal that whether oil price changes act as supply shocks or demand shocks for each industry depends on what kind of underlying shock drives the oil price changes, as well as on industry characteristics such as oil intensity. For most industries in the United States, the global demand shocks act mainly as positive demand shocks, and the oil-specific demand shocks act mainly as negative supply shocks. ${ }^{7}$ The oil supply shocks act mainly as negative supply shocks for oil-intensive industries and act mainly as negative demand shocks for less oil-intensive industries, as Lee and $\mathrm{Ni}$ (2002) found for exogenous oil price shocks.

Comparing the United States and Japan also enhances our understanding of the transmission mechanisms of oil price changes. In Japan, relative to the United States, the oil supply shock has weaker negative or statistically insignificant effects, the global demand shock has stronger positive effects, and most importantly, the oil-specific demand shock has positive rather than negative effects on the production of many industries. These findings seem to confirm the results of recent studies showing that the effects of oil price increases on Japan's economy are small or even positive and very different from those of other oil-importing countries. The positive response of production to the oil-specific demand shock might be the result of global demand shifts, especially in automobiles, toward more oil-efficient products made in Japan. In this sense, unlike in the United States, the oil-specific demand shocks act mainly as demand shocks rather than supply shocks for many industries in Japan.

The remainder of the chapter is organized as follows. Section 6.2 describes our empirical framework and the identified structural shocks to the global oil market. In section 6.3, we briefly discuss the estimation results for the domestic macroeconomy blocks for the United States and Japan. Section 6.4 reports the estimation results for the domestic industry blocks of both countries for each industry. In section 6.5 , we briefly survey the transmis-

6. Lee and Ni (2002) use Hamilton's (1996) "net oil price increase" as an oil price variable. Hooker (1996), in his reply to Hamilton (1996), casts doubt on the theoretical and empirical validity of using this variable to represent oil price shocks to the macroeconomy and argues that the use of cross-sectional data on industries, regions, or countries is required for a better understanding of the effects of oil price changes.

7. The global demand shocks and the oil-specific demand shocks are demand shocks to the global oil market and do not necessarily act as demand shocks to domestic aggregate or industrial markets. For instance, the global demand shocks may include nonoil sector productivity shocks that act as supply shocks to oil-importing countries' domestic markets. 
sion mechanisms of oil price changes and interpret our estimation results in more detail. We also consider the background of the differences between the results for the United States and Japan. Section 6.6 concludes. The appendix summarizes the estimation results under several alternative assumptions and specifications of the model to check the robustness of our main results.

\subsection{Empirical Framework}

\subsubsection{The Structural VAR Model}

Our VAR models comprise the global oil market block, the domestic macroeconomy block, and the domestic industry block. Following Lee and $\mathrm{Ni}$ (2002), we impose block recursive restrictions so that the identified shocks to the global oil market are the same for each country and the identified macroeconomic shocks are the same for each industry. In other words, domestic variables do not affect global oil market variables, and industrylevel variables do not affect aggregate variables. ${ }^{8}$ An identified VAR model has the following form:

$$
A_{0} X_{t}=A_{0} c+A_{0} B(L) X_{t}+u_{t}
$$

or

$$
A_{0}\left(\begin{array}{c}
X_{1 t} \\
X_{2 t} \\
X_{3 t}
\end{array}\right)=A_{0}\left(\begin{array}{c}
c_{1} \\
c_{2} \\
c_{3}
\end{array}\right)+A_{0}\left(\begin{array}{ccc}
B_{11}(L) & 0 & 0 \\
B_{21}(L) & B_{22}(L) & 0 \\
B_{31}(L) & B_{32}(L) & B_{33}(L)
\end{array}\right)\left(\begin{array}{c}
X_{1 t} \\
X_{2 t} \\
X_{3 t}
\end{array}\right)+\left(\begin{array}{c}
u_{1 t} \\
u_{2 t} \\
u_{3 t}
\end{array}\right),
$$

where $X_{1 t}$ is an $N_{1}$ dimensional column vector of global oil market variables; $X_{2 t}$ is an $N_{2}$ dimensional column vector of domestic aggregate variables; $X_{3 t}$ is an $N_{3}$ dimensional column vector of domestic industry-level variables; $c_{1}$, $c_{2}$, and $c_{3}$ are vectors of constants. Variable $B(L)$ is a block recursive matrix of polynomials of the lag operator $L$. Moreover, we assume that $A_{0}$ is a lower triangular matrix such that the reduced-form residuals can be decomposed into the structural shocks, $u_{t}$. The covariance matrix of the structural shocks, $E\left(u_{t} u_{t}^{\prime}\right)$, is given by an identity matrix of dimension $N\left(=N_{1}+N_{2}+N_{3}\right)$.

We use monthly data from 1973:1 to 2008:12 (that is, from January 1973 to December 2008). ${ }^{9}$ The lag length of the VAR is 12 . Following Kilian

8. This assumption may be too strong if movements in domestic economy in an individual country and linkages among countries have large impacts on the global oil market or if movements in an individual industry and linkages among industries have large impacts on the domestic aggregate economy. However, we impose these restrictions to enable comparison of impulse responses in different countries and different industries to the same structural shock to the global oil market. As mentioned in the appendix, allowing domestic aggregate variables to affect global oil market variables makes little difference to our estimation results.

9. Kilian (2009) also uses monthly data from 1973:1. Consistent data on the global oil market before 1973 are difficult to obtain. 
(2009), we consider oil supply shocks, shocks to the global demand for all industrial commodities, and demand shocks that are specific to the global oil market as structural shocks to the global oil market. Correspondingly, we use the following three variables in the global oil market block $\left(N_{1}=3\right)$ : world crude oil production; the industrial production of the Organization for Economic Cooperation and Development (OECD) countries plus major six nonmember economies (hereafter, world industrial production); ${ }^{10}$ and West Texas Intermediate spot crude oil prices. ${ }^{11}$ The last two variables differ from those used by Kilian (2009). ${ }^{12}$ We use the nominal price of oil rather than the real price because the deflator is endogenous with respect to the domestic macroeconomy, which would violate our assumption of a block recursive structure. ${ }^{13}$ For the domestic macroeconomy block, we only use aggregate industrial production $\left(N_{2}=1\right)$. For the domestic industry block, we use industrial production and producer prices $\left(N_{3}=2\right) .{ }^{14}$ We take first differences in the logs of all variables. The data on industrial production in each block and producer prices are seasonally adjusted. The ordering of the variables in the VAR is as described before. ${ }^{15}$ The reduced-form VAR is estimated consistently by the method of ordinary least squares.

\subsubsection{Structural Shocks to the Global Oil Market}

We follow Kilian (2009) to identify the structural shocks to the global oil market. The oil supply shocks are innovations to global oil production that are assumed not to respond to innovations to the demand for oil within the same month. The global demand shocks are innovations to world industrial production that cannot be explained by the oil supply shocks. The oil-specific demand shocks are innovations to the oil price that cannot be explained by either the oil supply shocks or the global demand shocks. The oil-specific demand shocks are supposed to reflect changes in precautionary demand arising from uncertainty about future oil supply, and may also reflect changes in speculative demand. Although we use slightly different data from those used by Kilian (2009), our estimation results for the global oil market block are similar to his. Figure 6.1 plots the historical evolution

10. This index can be downloaded from OECD websites. The six nonmember economies are Brazil, China, India, Indonesia, the Russian Federation, and South Africa.

11. Data for before 1982 are posted prices.

12. Kilian (2009) uses an original measure of global real economic activity based on dry cargo freight rates and the U.S. refiner acquisition cost of imported crude oil deflated by the U.S. Consumer Price Index (CPI) (both in natural logs). The data on world crude oil production used by Kilian (2009) are the same as those we use.

13. Hamilton (2008) and Rotemberg and Woodford (1996) point out this problem. We do not use the refiner acquisition cost of imported crude oil for the same reason.

14. We use the Index of Industrial Production published by the Federal Reserve Board and that published by the Japanese Ministry of Economy, Trade, and Industry. For prices data, we use the Producer Price Index from the U.S. Bureau of Labor Statistics and the Corporate Goods Price Index from the Bank of Japan.

15. As mentioned in the appendix, changing the ordering in the domestic industry block so that prices rather than production come first makes little difference to the estimation results. 
Oil Supply Shocks

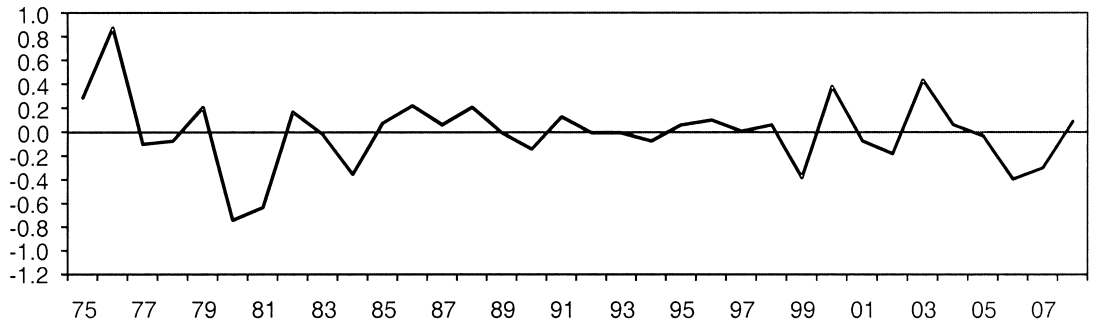

Global Demand Shocks

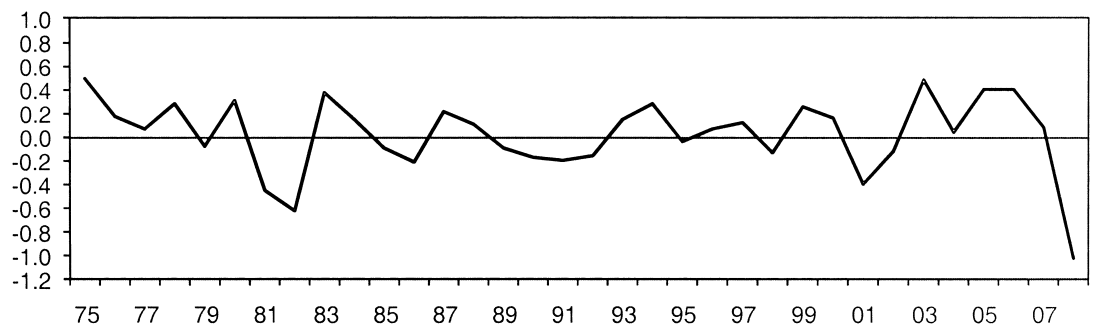

Oil -Specific Demand Shocks

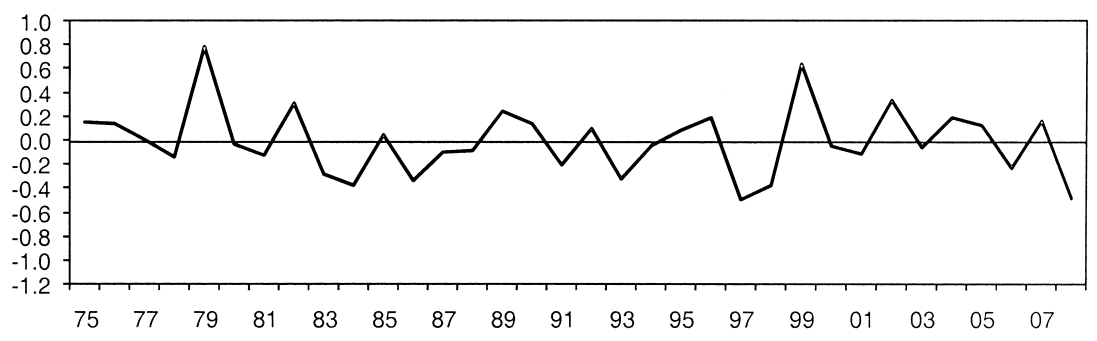

Fig. 6.1 Historical evolution of the structural shocks

(annual averages) of the structural shocks implied by our model. As shown by Kilian (2009), there was no unanticipated disruption of oil supply in 1978 or 1979 but there were disruptions in 1980 and 1981 associated with the Iran-Iraq War. Positive shocks to the global demand have been repeated since 2003 and a large negative shock occurred in 2008. The occurrence of the oil-specific demand shocks has been constant throughout the sample period.

The cumulative responses of the three variables in the global oil market block to one-standard-deviation structural shocks identified earlier are shown in figure 6.2. The oil supply shock has been normalized to represent a negative shock to oil production, whereas the other shocks have been normalized to represent positive shocks such that all shocks tend to raise the oil price. One-standard-error bands computed from a bootstrap method are 

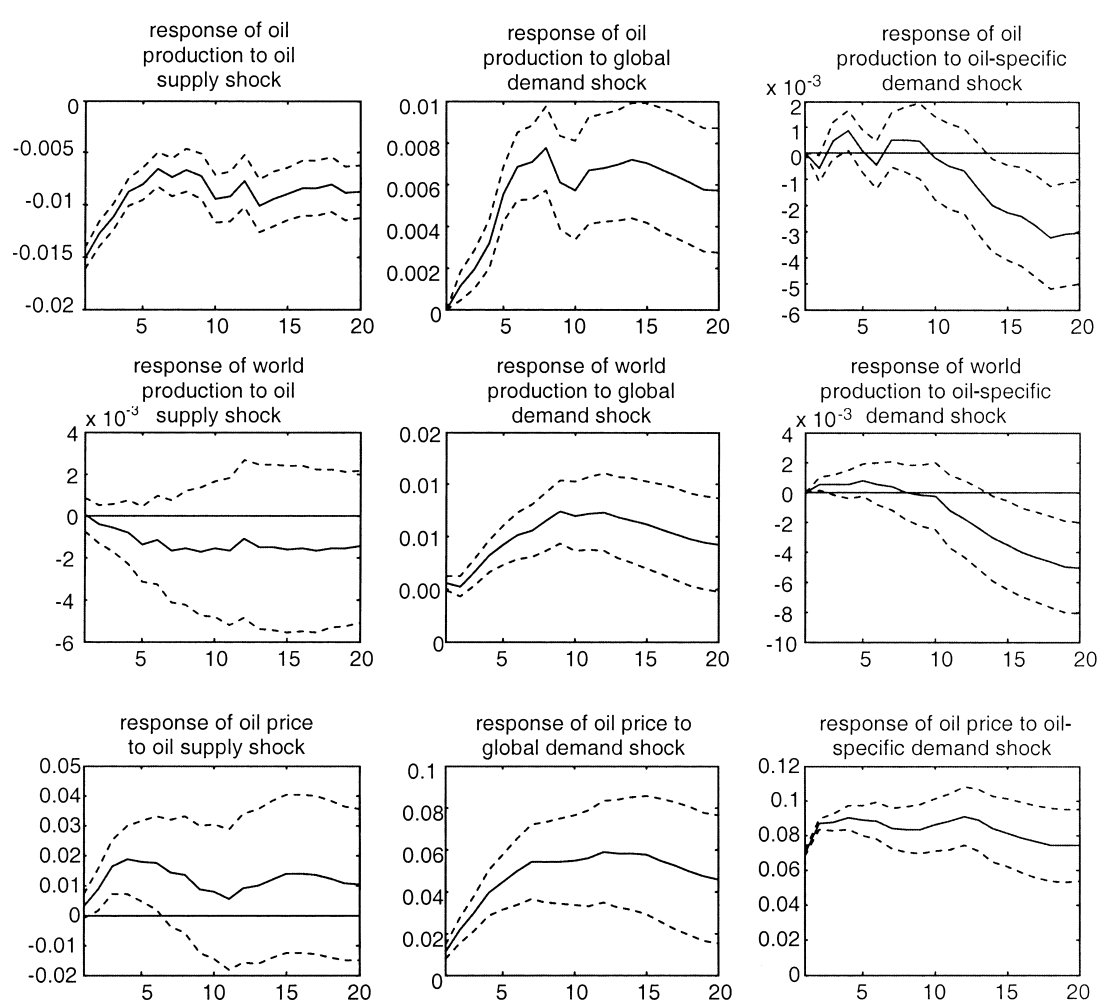

Fig. 6.2 Cumulative responses in the global oil market block

indicated by dashed lines. Of the three shocks, the oil-specific demand shock has the largest and most persistent effect on the oil price. It sharply raises the oil price on impact, which remains high for a long time. The global demand shock also has a large and persistent effect, causing a gradual increase in the oil price that lasts for about a year (twelve months). The oil supply shock has only a small and transitory effect, causing a gradual increase in the oil price that lasts for about four months. Whereas an unexpected global demand increase is associated with increases in oil production and world industrial production, an unexpected oil-specific demand increase is associated with decreases, following a ten-month lag, in oil production and world industrial production. An unexpected disruption of oil supply is also associated with a decrease in oil production and its effect on world industrial production is statistically insignificant. These results imply that the effects of the three shocks on the oil price differ in magnitude and persistence. Moreover, the effects of oil price changes on oil production and world industrial production are very different depending on what kind of underlying shock drives the oil price changes. 
Oil Supply Shocks

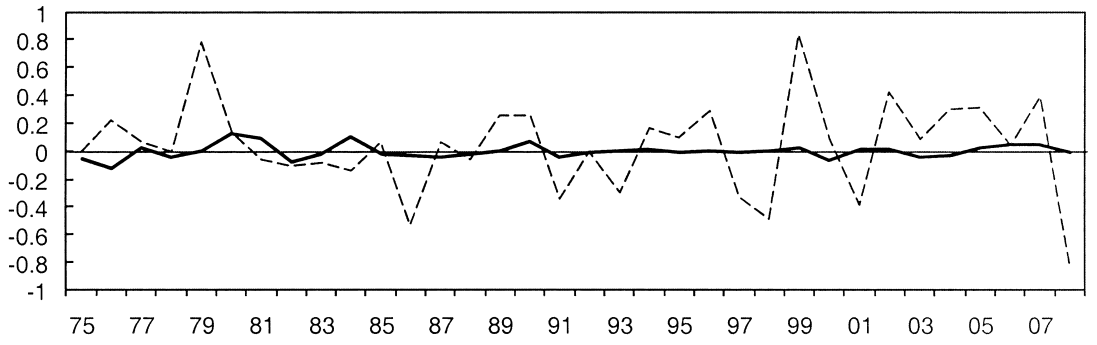

Global Demand Shocks

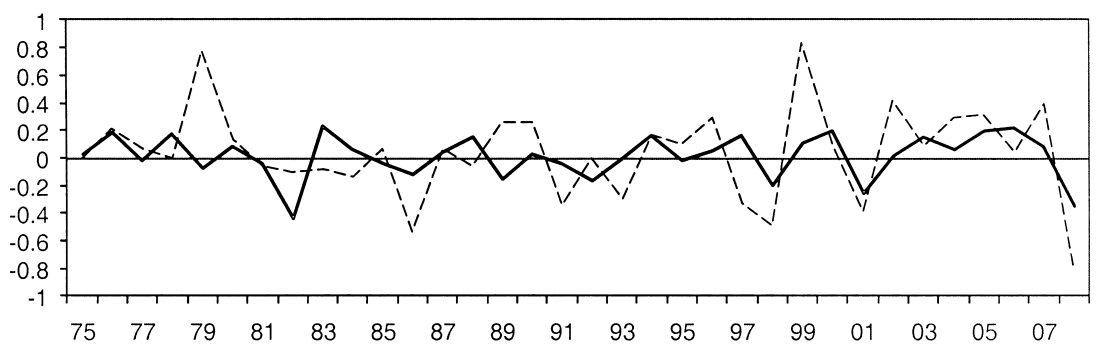

Oil-Specific Demand Shocks

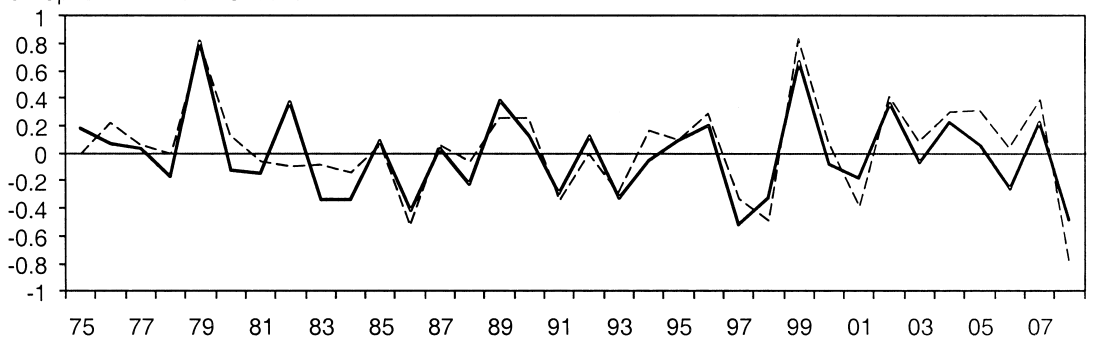

Fig. 6.3 Historical decomposition of nominal oil price

Figure 6.3 plots a historical decomposition of the oil price into the contribution of the structural shocks. The annual rate of change (difference in logs) in the oil price is indicated by the dashed line in each panel. ${ }^{16}$ The oil supply shocks made a small contribution to nominal oil price movements, which is consistent with the finding of Kilian (2009) for the real price of oil. Most changes in the nominal oil price before 2000 were driven by the oil-specific demand shocks. Rapid temporary changes, such as the sharp fall following the collapse of the Organization of the Petroleum Exporting

16. Since the model contains a constant term, the sum of the contribution of the three shocks is not equal to the rate of change in the oil price. The same applies to the historical decompositions in figures 6.5 and 6.7 . 
Countries (OPEC) cartel in late 1985 and the spike after Iraq's invasion of Kuwait in 1990 (which are not obvious from the annual figures), were also attributable mainly to the oil-specific demand shocks. Meanwhile, the persistent surge in the oil price from 2002 and the sharp fall in 2008 were driven by the global demand shocks as well as by the oil-specific demand shocks.

\subsection{Macroeconomic Effects of Oil Price Changes}

In this section, we briefly discuss the estimation results for the domestic macroeconomy block in our models for the United States and Japan and compare them. The domestic macroeconomy block includes only one variable, aggregate industrial production. The shock to this block captures all domestic aggregate disturbances not driven by the structural shocks identified in the global oil market block. Because our main concern in this chapter is the industry-level effects of oil price changes and how these effects compare in the United States and Japan, we model the domestic macroeconomy block as simply as possible. ${ }^{17}$

\subsubsection{Effects on Aggregate Production in the United States}

Figure 6.4 shows the cumulative responses of aggregate industrial production in the United States to one standard deviation of the three structural shocks identified in the global oil market block and the domestic aggregate shock. The three structural shocks to the global oil market, which all tend to raise the oil price, have very different effects on domestic macroeconomic activity. Whereas the oil supply shock and the oil-specific demand shock reduce industrial production, the global demand shock raises production for about ten months. Whereas the decrease in production caused by the oil supply shock lasts for about ten months, the decrease caused by the oilspecific demand shock accelerates around ten months after the shock. The domestic aggregate shock raises production gradually and persistently.

Figure 6.5 plots a historical decomposition of U.S. aggregate industrial production into the contribution of the three global shocks and the domestic aggregate shock. The annual rate of change in U.S. industrial production is indicated by the dashed line in each panel. Changes in U.S. industrial production were driven mainly by the global demand shocks and the domestic aggregate shocks. Because U.S. production accounts for a large share of world production, it seems natural that the global demand shocks make a substantial contribution to U.S. production. It is nonetheless remarkable that movements in U.S. production in the 2000s (that is, 2000 to 2010) have been driven mainly by the global demand shocks despite the fact that the

17. As mentioned in the appendix, we tried an alternative specification of the domestic macroeconomy block that includes the short-term nominal interest rate and the real effective exchange rate in addition to aggregate industrial production. This extension of the domestic macroeconomy block, however, made little difference to our estimation results. 
response of U.S.

production to oil supply

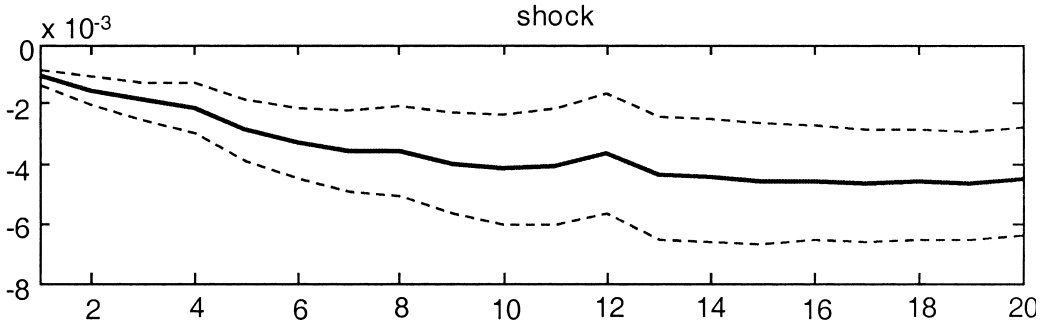

response of U.S.

production to global

demand shock

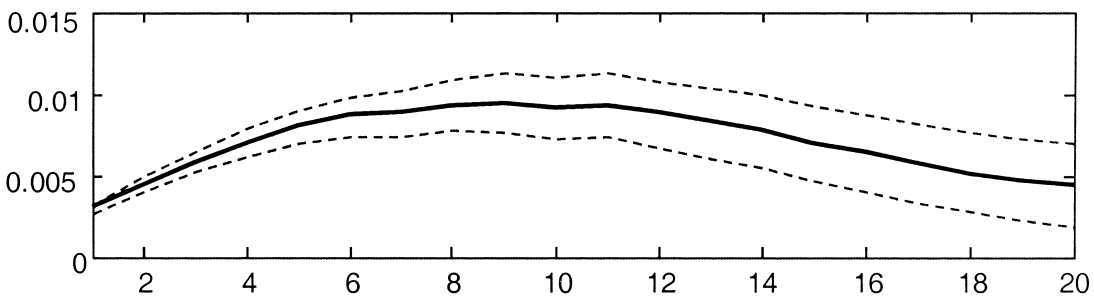

response of U.S.

production to oil-

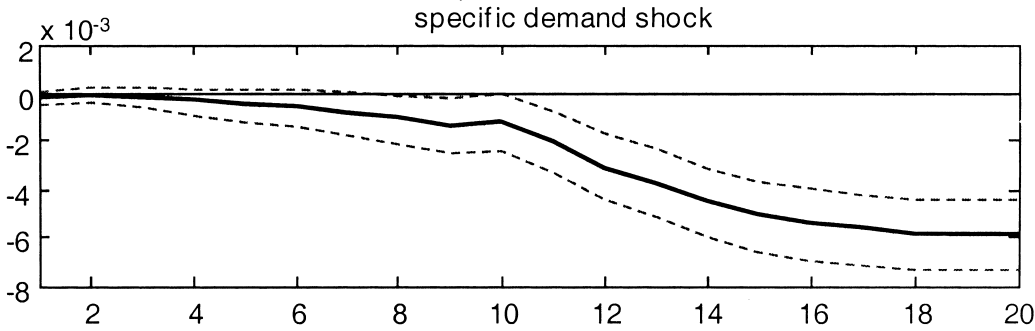

response of U.S.

production to domestic

aggregate shock

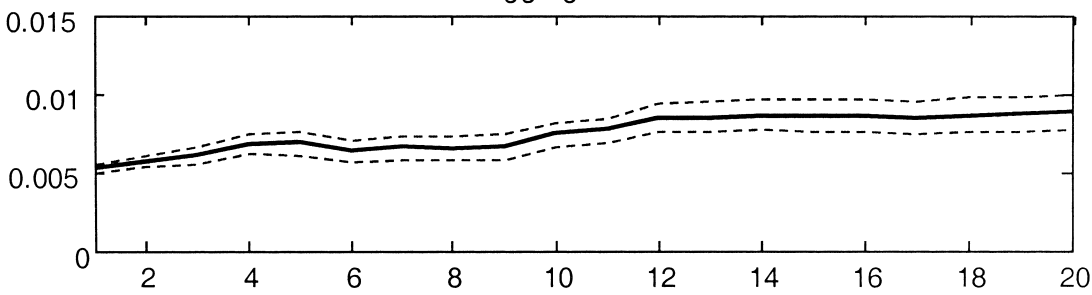

Fig. 6.4 Cumulative responses of aggregate production (U.S.) 
Oil Supply Shocks

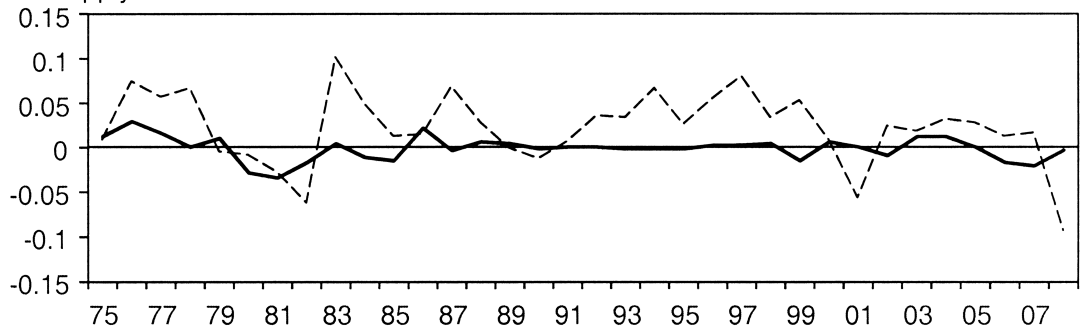

Global Demand Shocks

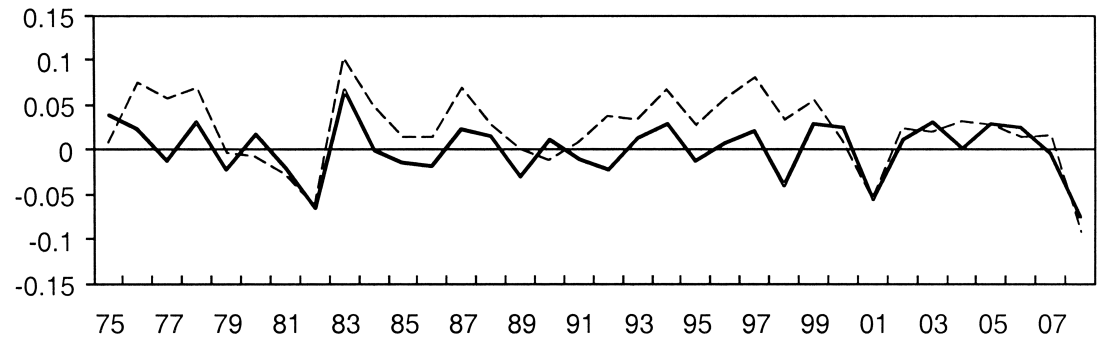

Oil-Specific Demand Shocks

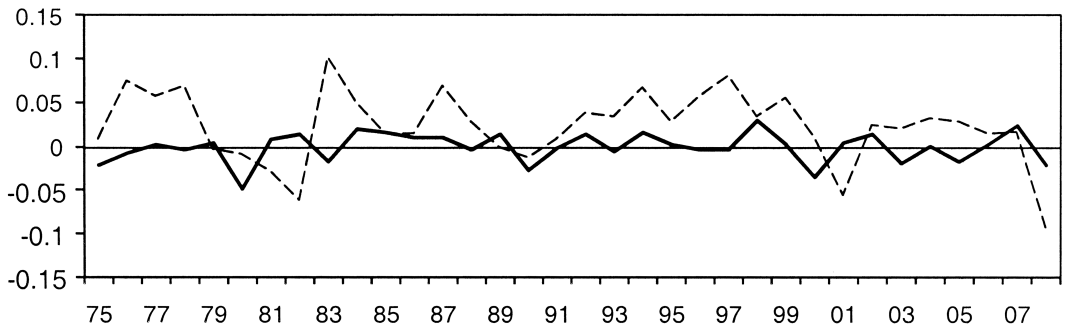

Domestic Aggregate Shocks

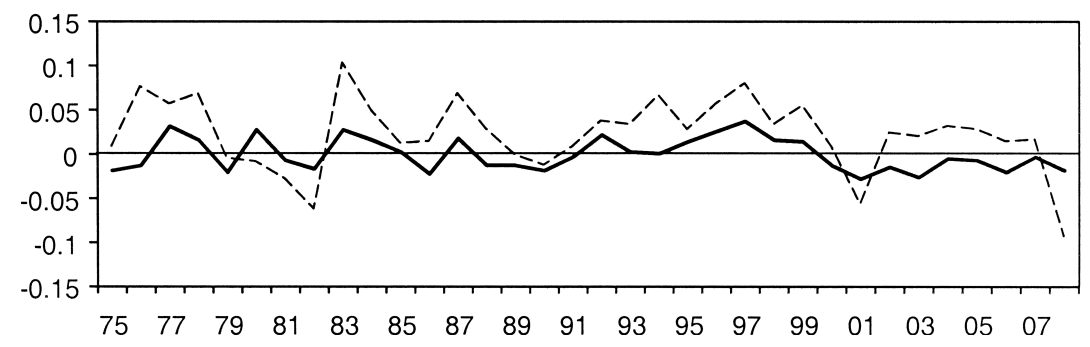

Fig. 6.5 Historical decomposition of aggregate production (U.S.) 
U.S. share of world production declined over this period. By contrast, the contribution of the domestic aggregate shocks has declined in the 2000s, although they made a substantial contribution to U.S. expansion in the 1990s. Because the oil price and industrial production move in the same direction in response to the global demand shocks, the relationship between them seems to have changed in the 2000s, when movements in these two variables have been driven by the global demand shocks.

\subsubsection{Effects on Aggregate Production in Japan}

The cumulative responses of Japan's aggregate industrial production are shown in figure 6.6. They are rather different from those of the United States. The effect of the oil supply shock on Japan's industrial production is statistically insignificant. The positive effect of the global demand shock is larger and more persistent than in the United States. Most importantly, the oilspecific demand shock has a positive, rather than negative, effect on Japan's production, at least in the short run. Production starts decreasing around half a year (six months) after a positive oil-specific demand shock. These findings suggest that, unlike in other oil-importing countries including the United States, the effects of oil price increases in Japan are either negligibly negative or even positive. The effect of the domestic aggregate shock in Japan is larger than in the United States.

A historical decomposition of Japan's aggregate industrial production is shown in figure 6.7. The annual rate of change in Japan's industrial production is indicated by the dashed line in each panel. As in the United States, changes in Japan's industrial production have been driven mainly by the global demand shocks and the domestic aggregate shocks. Whereas the contraction of the 1990s was driven mainly by the domestic aggregate shocks, the expansion of the 2000s was driven mainly by the global demand shocks. Relative to the U.S. case, the domestic aggregate shocks have made a large contribution to Japan's industrial production.

\subsection{Industry-Level Effects of Oil Price Changes}

In this section, we report the estimation results for the domestic industry block. As mentioned in the introduction, our motivation for using industrylevel data is to investigate the transmission mechanisms of oil price changes in the U.S. and Japan's economies. In particular, an important question is whether oil price changes act as supply shocks or demand shocks for each industry. Before reporting the estimation results, we briefly summarize basic statistics on the industrial structures of the United States and Japan, which may characterize the supply and demand sides of the transmission mechanisms. We discuss the implications of the estimation results in detail in section 6.5. 
response of JP Production to

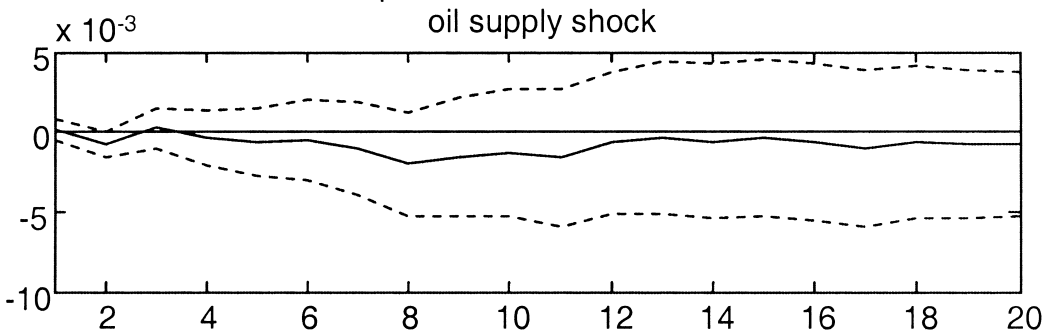

response of JP Production to global demand shock

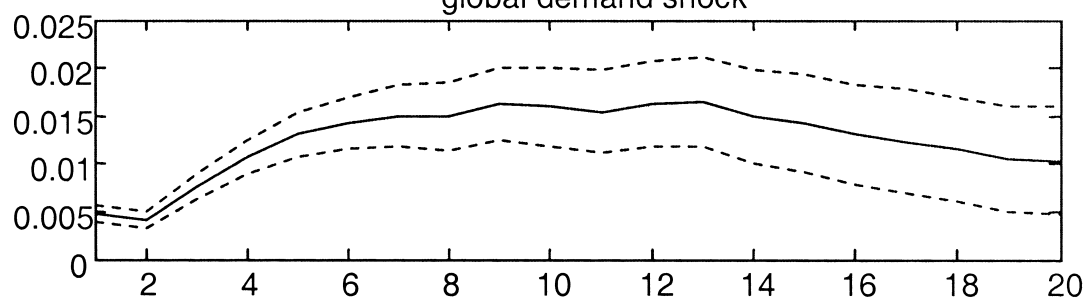

response of JP Production to oil-specific demand shock

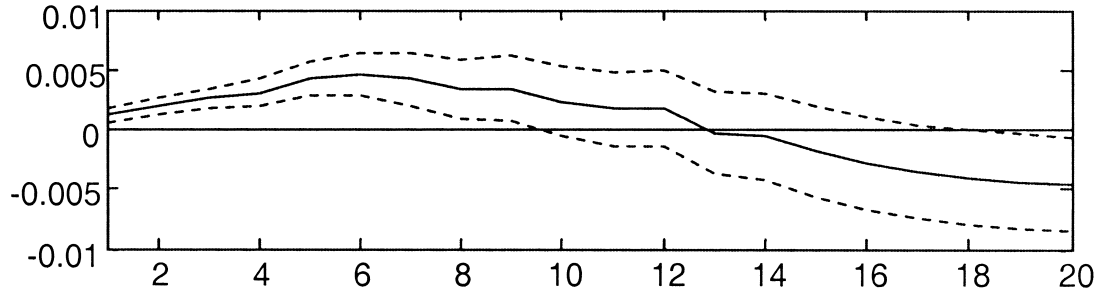

response of JP Production to domestic aggregate shock

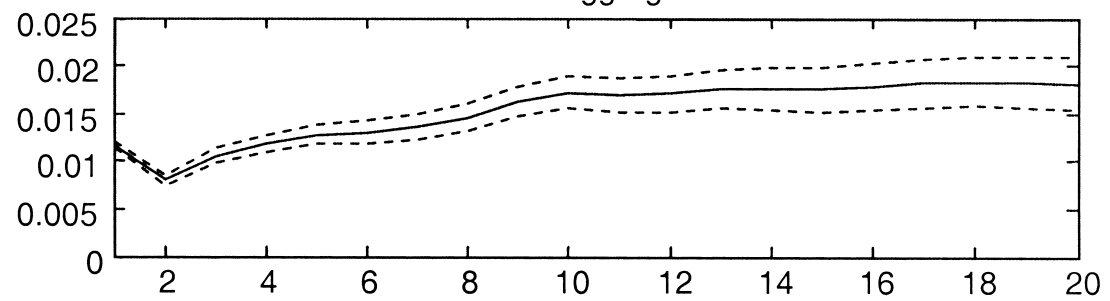

Fig. 6.6 Cumulative responses of aggregate production (Japan) 
Oil Supply Shocks

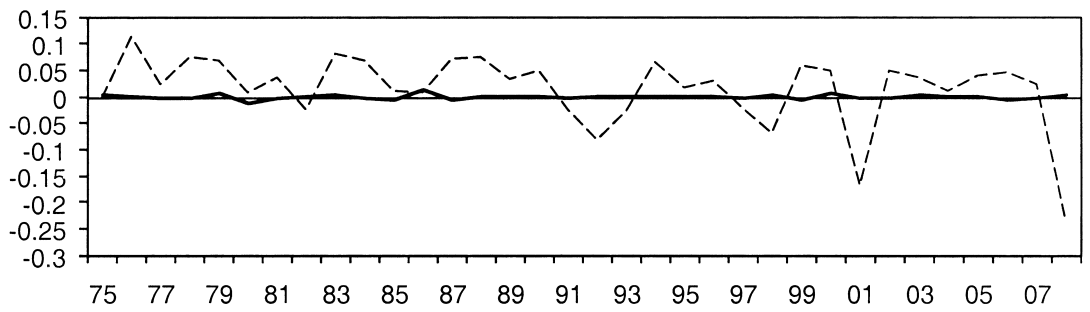

Global Demand Shocks

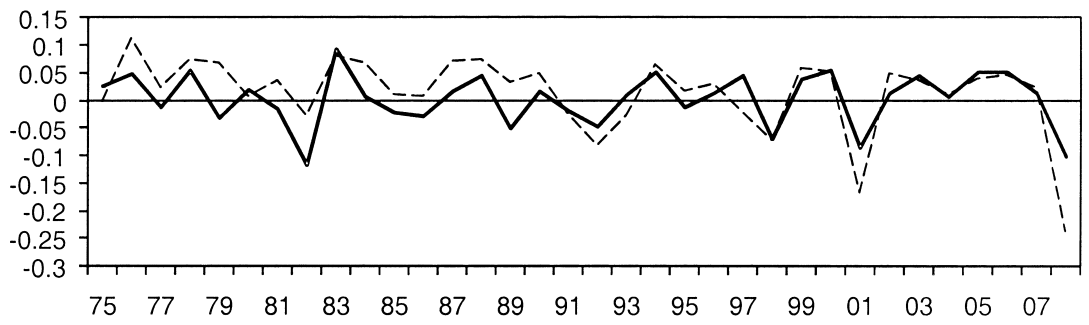

Oil-Specific Demand Shocks

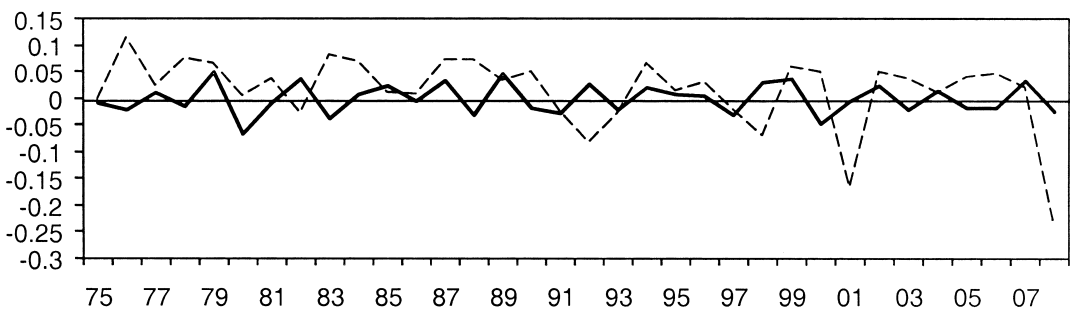

Domestic Aggregate Shocks

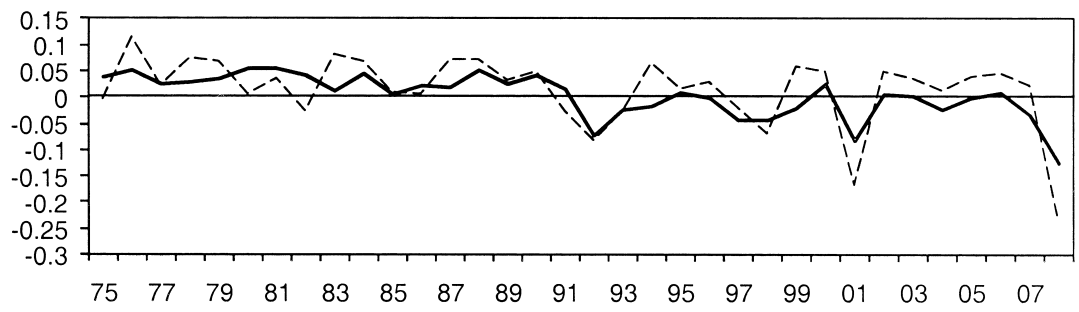

Fig. 6.7 Historical decomposition of aggregate production (Japan) 


\subsubsection{Basic Statistics on Industrial Structures}

Table 6.1 shows the value-added shares of industrial production for the twelve industries in the United States and Japan selected for the present study. Although the total share of our selected industries accounts for only around 40 percent of U.S. aggregate manufacturing production, they include key industries for the transmission of oil price changes, such as petroleum refineries and automotive products, as discussed in section 6.5. Because we must match industry-level data on production and prices, we cannot select broadly defined (three-digit North American Industry Classification Sys-

Table 6.1 Value-added share of production

\begin{tabular}{lcc}
\hline \multicolumn{3}{c}{ U.S. } \\
\hline Sndustry & Share in 2006 (\%) & Share in 1973 (\%) \\
\hline Fabricated metal product & 5.5 & 6.7 \\
Chemical materials & 5.4 & 4.4 \\
Machinery & 5.0 & 8.6 \\
Petroleum refineries & 3.9 & 1.3 \\
Automotive products & 3.3 & 3.5 \\
Plastics and rubber products & 3.2 & 2.9 \\
Paper & 2.6 & 3.1 \\
Nonmetallic mineral product & 2.3 & 2.7 \\
Furniture and related product & 1.5 & 1.6 \\
Wood product & 1.4 & 2.1 \\
Iron and steel products & 1.4 & 3.1 \\
Electrical equipment & 0.6 & 1.1 \\
12-industry total & 36.3 & 41.3 \\
\hline
\end{tabular}

\begin{tabular}{lcc}
\hline \multicolumn{2}{c}{ Japan } & \\
\hline Industry & Share in 2005 (\%) & Share in 1975 (\%) \\
\hline Electric machinery and equipment & 18.4 & 11.0 \\
Transportation equipment & 16.9 & 11.8 \\
General machinery and equipment & 13.2 & 12.8 \\
Chemicals and related products & 11.8 & 9.5 \\
Iron and steel products & 6.0 & 6.6 \\
Metal products & 5.7 & 5.0 \\
Plastic products & 3.8 & 2.8 \\
Ceramic, stone, and clay products & 2.9 & 5.7 \\
Pulp, paper, and related products & 2.4 & 3.5 \\
Nonferrous metals and products & 2.1 & 1.9 \\
Precision instruments & 1.0 & 1.6 \\
Petroleum and coal products & 1.0 & 2.9 \\
12-industry total & 85.2 & 75.3 \\
\hline
\end{tabular}

Sources: Industrial Production, Federal Reserve Board. Indices of Industrial Production, Japanese Ministry of Economy, Trade, and Industry. 
tem [NAICS]) industries. For Japan, where the total value-added share of our selected industries is around 80 percent, data on both production and prices for broadly defined industries are available, although lengthy timeseries data at the highly disaggregated industry level are not available. For instance, petroleum refineries are included in "petroleum and coal products" and automotive products are included in "transportation equipment." Table 6.1 also shows that some industries' shares changed considerably during our sample period. For instance, in the United States, from 1973 to 2006, chemical materials and petroleum refineries increased their shares, whereas fabricated metal products and machinery decreased their shares. In Japan, from 1975 to 2005, shares for the electrical machinery and transportation equipment increased, whereas the share for the ceramic, stone, and clay products decreased.

We consider two industry characteristics: oil intensity and export dependence. The former relates to the cost share of oil in production and is a key characteristic for the supply channel in the transmission of oil price changes, as discussed in section 6.5. The latter relates to the export share of shipments and is a key characteristic for the effects of the global demand shocks. We measure these characteristics for both countries based on the 2000 Japan-U.S. input-output table from Japan's Ministry of Economy, Trade, and Industry.

Table 6.2 shows the cost share of oil in each industry in both countries. ${ }^{18}$ The oil intensity of the petroleum and coal products (which includes petroleum refineries) is particularly high in both countries. Oil intensity is also relatively high in ceramics, stone, and clay products, chemical products, steel and steel products, and nonsteel metals and products. We term these industries "oil-intensive industries" and refer to the others as "less oil-intensive industries." Based on the twelve-industry average, Japan is less oil-intensive than the United States.

Table 6.3 shows the export share of shipments in each industry in both countries. The export dependences of precision instruments, electric machinery, general machinery, and transportation equipment (which includes automotive products) are particularly high in both countries. These industries are termed "export-dependent industries." Based on the twelve-industry average, Japan is more export-dependent than the United States.

\subsubsection{Effects of Oil Supply Shocks on Industry-Level Production and Prices}

Figures 6.8 through 6.21 illustrate the estimated cumulative responses of production and prices of the twelve selected industries in the United States and Japan to one standard deviation of the three structural shocks identified in the global oil market block. In figures 6.10 through 6.21, each 
Oil intensity (cost share of mining and petroleum and coal products)

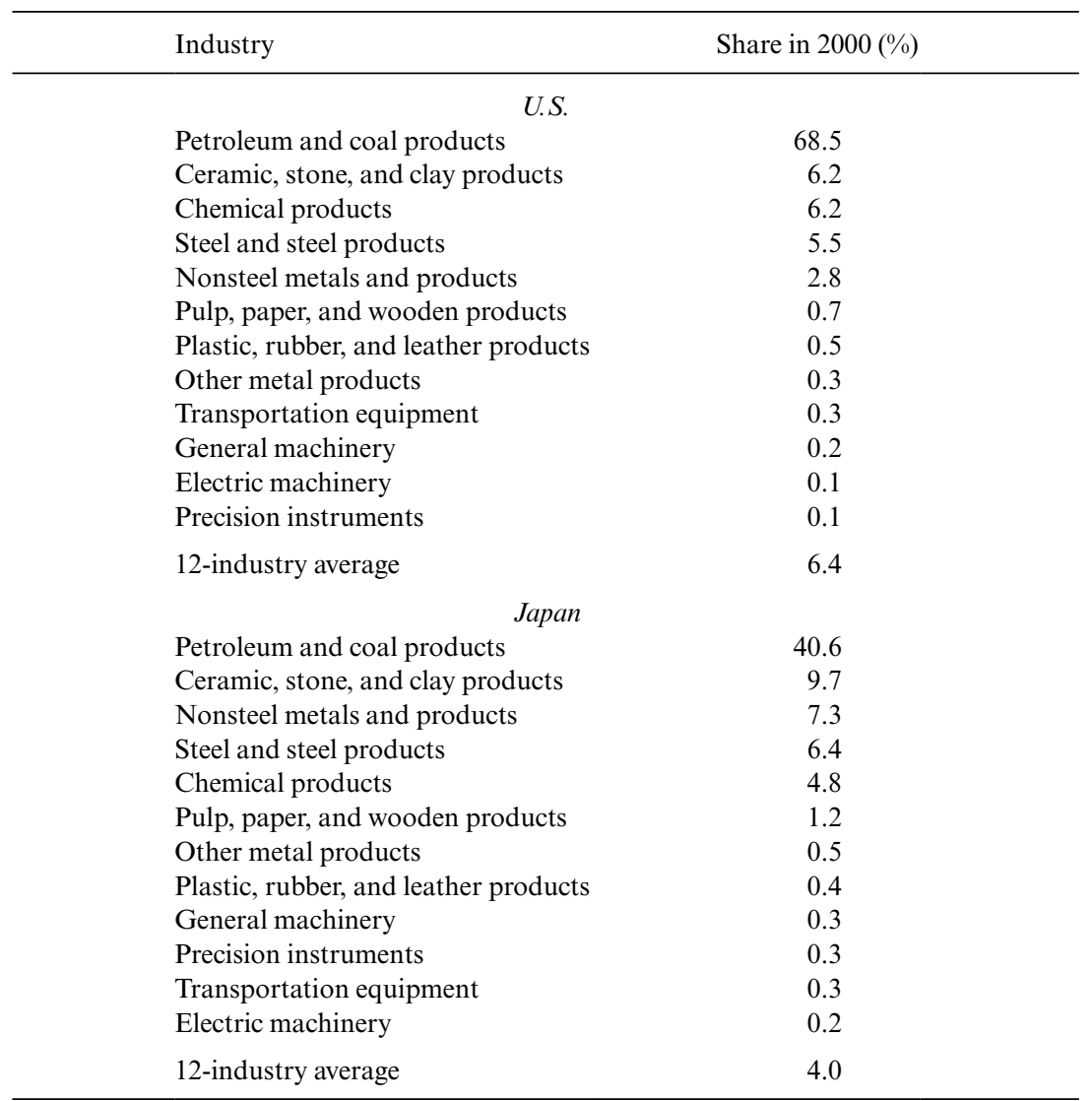

Sources: The 2000 Japan-U.S. input-output table, Japanese Ministry of Economy, Trade, and Industry.

response is accompanied by one-standard-error bands computed from a bootstrap method. The graphs for the selected industries are presented in order of oil intensity. Note that the scales of the responses are different for different industries. For cross-industry comparisons, we show the magnitudes of the twelve-month cumulative responses for all the selected industries in the United States in figure 6.8 and those in Japan in figure 6.9. In addition, in tables 6.4 and 6.5, we summarize the signs of the peak responses within twenty months to each shock in the United States and Japan, respectively, following Lee and $\mathrm{Ni}$ (2002). ${ }^{19}$ These tables enable us to identify the main

19. Rather than plot the cumulative responses of first-difference series to permanent level shocks as we do, Lee and $\mathrm{Ni}$ (2002) plot the responses of level variables to temporary level shocks. Therefore, our responses have different interpretations, particularly in the long run, from theirs. 
Table 6.3 Export dependence (export share of shipments)

\begin{tabular}{lc}
\hline Industry & Share in $2000(\%)$ \\
& \\
Electric machinery & 30.2 \\
Precision instruments & 29.6 \\
General machinery & 26.3 \\
Transportation equipment & 20.4 \\
Nonsteel metals and products & 17.3 \\
Chemical products & 17.2 \\
Plastic, rubber, and leather products & 9.6 \\
Pulp, paper, and wooden products & 6.6 \\
Steel and steel products & 6.4 \\
Ceramic, stone, and clay products & 6.4 \\
Other metal products & 6.3 \\
Petroleum and coal products & 5.7 \\
12-industry average & 14.9 \\
& \\
& \\
Precision instruments & 33.9 \\
Transportation equipment & 33.4 \\
Electric machinery & 33.1 \\
General machinery & 27.9 \\
Steel and steel products & 17.0 \\
Chemical products & 15.6 \\
Nonsteel metals and products & 15.3 \\
Plastic, rubber, and leather products & 8.6 \\
Ceramic, stone, and clay products & 6.9 \\
Other metal products & 3.8 \\
Pulp, paper, and wooden products & 2.1 \\
Petroleum and coal products & 1.6 \\
12-industry average & 17.1 \\
\hline
\end{tabular}

Sources: The 2000 Japan-U.S. input-output table, Japanese Ministry of Economy, Trade, and Industry.

effects of each structural shock for each industry. If production and price move in the same (opposite) direction after a shock, the dominant effect of that shock is on the demand (supply) side.

First we examine the responses of production and prices to the oil supply shock in the United States, as shown in figures 6.10 and 6.11. In most industries in the United States, an unexpected disruption of oil supply causes a gradual decline in production that lasts for about a year. The production of petroleum refineries declines on impact and then continues to decline gradually and persistently. The responses of prices vary across industries. An unexpected oil supply disruption significantly raises the price of petroleum refineries and reduces the prices of wood product and electrical equipment. It tends to raise the prices of oil-intensive industries and tends to reduce the prices of less oil-intensive industries, although these effects for many 
Oil Supply Shock

Petroleum refineries Non-metallic mineral product Chemical materials Iron and steel products Paper Plastics and rubber products Fabricated metal product Automotive products Furniture and related product Wood product Machinery Electrical equipment

Global Demand Shock

Petroleum refineries Non-metallic mineral product Chemical materials Iron and steel products

Plastics and rubber products Fabricated metal product Automotive products Furniture and related product Wood product Machinery Electrical equipment

Oil-Specific Demand Shock

Petroleum refineries Nonmetallic mineral product Chemical materials Iron and steel products Paper Plastics and rubber products Fabricated metal product Automotive products Furniture and related product Wood product Machinery Electrical equipment
Responses of U.S. output and price to oil supply shock

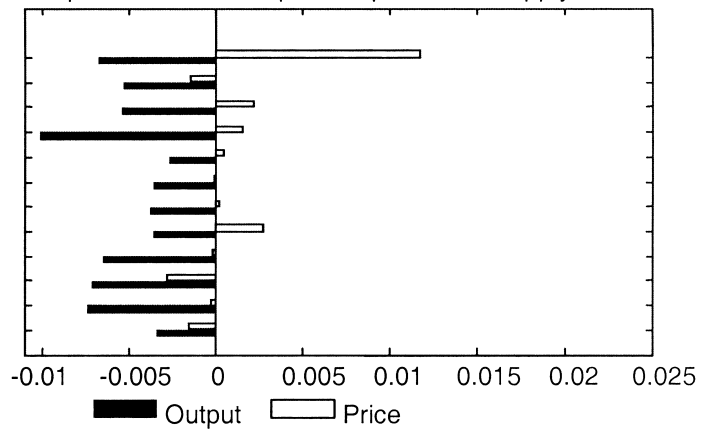

Responses of U.S. output and price to global demand shock

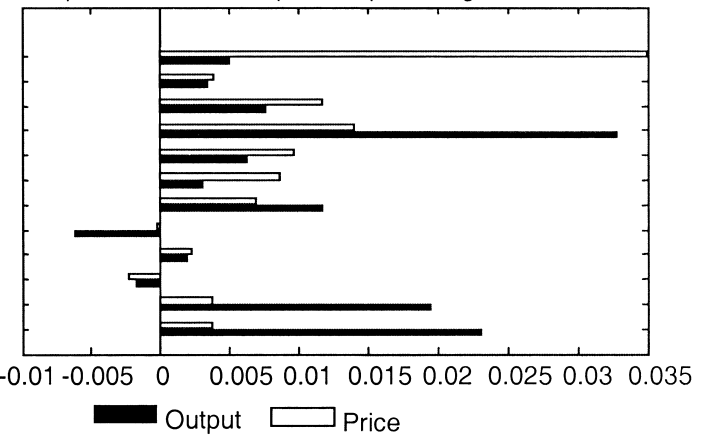

Responses of US output and price to oil-specific demand shock

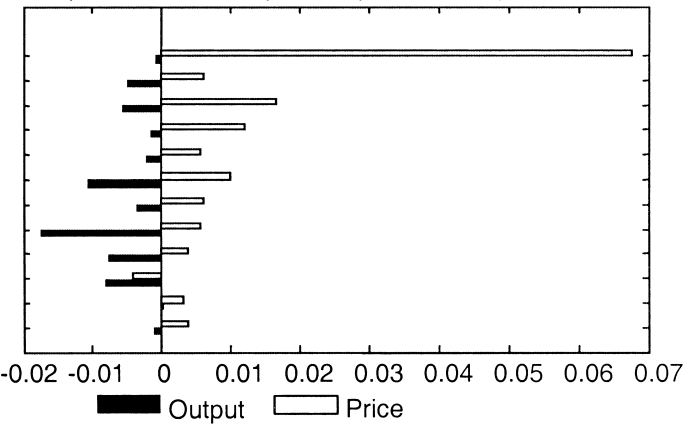

Fig. 6.8 Magnitudes of twelve-month cumulative responses (U.S.)

industries are only partially (in limited periods) statistically significant. This implies that the oil supply shocks act mainly as supply shocks for oilintensive industries and act mainly as demand shocks for less oil-intensive industries. This finding is similar to that obtained by Lee and $\mathrm{Ni}$ (2002) for exogenous oil price shocks.

The responses of production and prices to the same shock in Japan are 
Oil Supply Shock

Petroleum and coal products Ceramic, stone and clay products Non-ferrous metals Iron and steel

Chemicals and related products Pulp, paper and related products Metal products Plastic products General machinery and equipment Precision instruments Transportation equipment Electrical machinery and equipment

Global Demand Shock

Petroleum and coal products Ceramic, stone and clay products Non-ferrous metals Iron and steel

Chemicals and related products Pulp, paper and related products Metal products Plastic products

General machinery and equipment Precision instruments Transportation equipment Electrical machinery and equipment

Oil-Specific Demand Shock

Petroleum \& coal products Ceramic, stone \& clay products Non-ferrous metals Iron \& steel

Chemicals \& related products Pulp, paper \& related products Metal products Plastic products General machinery \& equipment Precision instruments Transportation equipment Electrical machinery \& equipment
Responses of JP output and price to oil supply shock

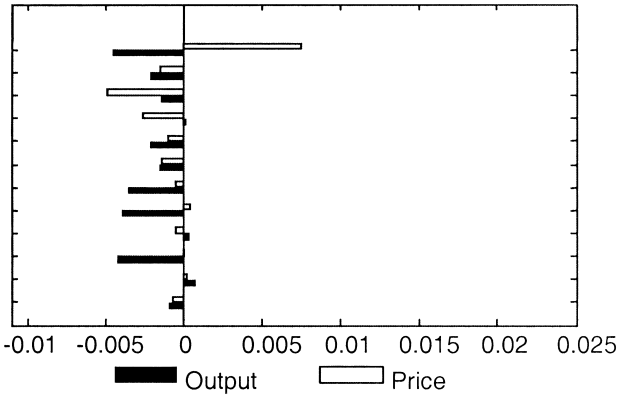

Responses of JP output and price to global demand shock

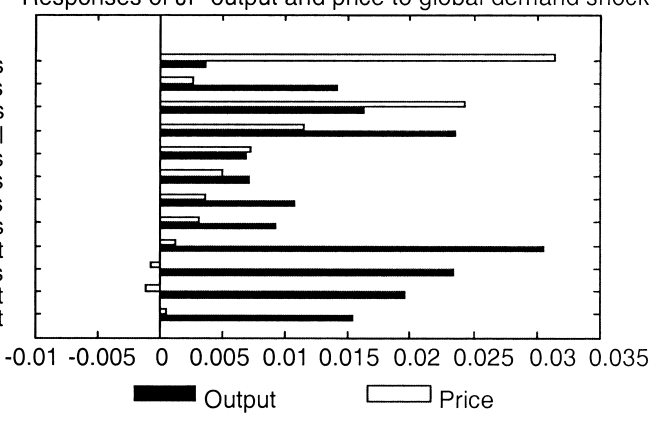

Responses of JP output and price to oil-specific demand shock

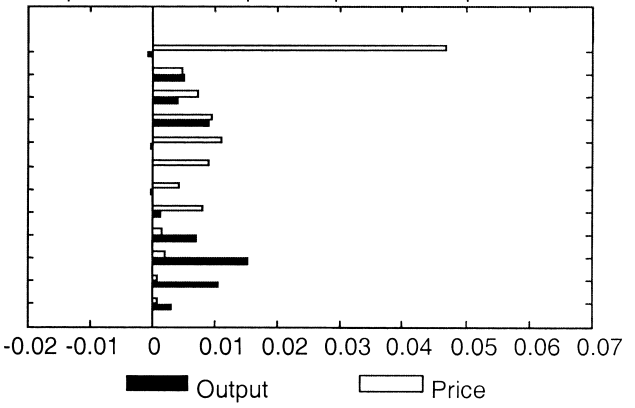

Fig. 6.9 Magnitudes of twelve-month cumulative responses (Japan)

shown in figures 6.12 and 6.13. An unexpected disruption of oil supply gradually decreases petroleum and coal production, which includes production of petroleum refineries, and this lasts for about a year. There are declines in production of many other industries, but only partially statistically significant. Disruption of oil supply gradually increases prices of petroleum refineries, and this also lasts for about a year. There are price falls in other oil-intensive industries such as ceramic, stone, and clay products and iron and steel products, but only partially statistically significant. 
Oil supply shock

\begin{tabular}{|c|c|c|c|}
\hline Industry & $\begin{array}{c}\text { Peak effect } \\
\text { on output }\end{array}$ & $\begin{array}{l}\text { Peak effect } \\
\text { on prices }\end{array}$ & Oil supply shock effects \\
\hline Petroleum refineries & $-*$ & $+*$ & Decrease in supply \\
\hline Nonmetallic mineral product & 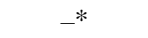 & - & Decrease in demand \\
\hline Chemical materials & $-*$ & $+^{*}$ & Decrease in supply \\
\hline Iron and steel products & - & $+^{*}$ & Decrease in supply \\
\hline Paper & -* & 0 & \\
\hline Plastics and rubber products & -* & 0 & \\
\hline Fabricated metal product & -* & 0 & \\
\hline Automotive products & -* & $+^{*}$ & Decrease in supply \\
\hline Furniture and related product & -* & 0 & \\
\hline Wood product & $-*$ & $-*$ & Decrease in demand \\
\hline Machinery & $-*$ & 0 & \\
\hline Electrical equipment & - & -* & Decrease in demand \\
\hline
\end{tabular}

\begin{tabular}{|c|c|c|c|}
\hline \multicolumn{4}{|c|}{ Global demand shock } \\
\hline Industry & $\begin{array}{l}\text { Peak effect } \\
\text { on output }\end{array}$ & $\begin{array}{l}\text { Peak effect } \\
\text { on prices }\end{array}$ & $\begin{array}{l}\text { Global demand shock } \\
\text { effects }\end{array}$ \\
\hline Petroleum refineries & $+*$ & $+*$ & Increase in demand \\
\hline Nonmetallic mineral product & $+*$ & $+^{*}$ & Increase in demand \\
\hline Chemical materials & $+*$ & $+^{*}$ & Increase in demand \\
\hline Iron and steel products & $+*$ & $+*$ & Increase in demand \\
\hline Paper & $+*$ & $+*$ & Increase in demand \\
\hline Plastics and rubber products & $+^{*}$ & $+^{*}$ & Increase in demand \\
\hline Fabricated metal product & $+^{*}$ & $+^{*}$ & Increase in demand \\
\hline Automotive products & Mixed & $+^{*}$ & \\
\hline Furniture and related product & Mixed & $+*$ & \\
\hline Wood product & Mixed & $-{ }^{*}$ & \\
\hline Machinery & $+*$ & $+^{*}$ & Increase in demand \\
\hline Electrical equipment & $+^{*}$ & $+^{*}$ & Increase in demand \\
\hline
\end{tabular}

Oil-Specific Demand Shock

\begin{tabular}{lccc}
\hline Industry & $\begin{array}{c}\text { Peak effect } \\
\text { on output }\end{array}$ & $\begin{array}{c}\text { Peak effect } \\
\text { on prices }\end{array}$ & $\begin{array}{c}\text { Oil-specific demand } \\
\text { shock effects }\end{array}$ \\
\hline Petroleum refineries & $-^{*}$ & $+^{*}$ & Decrease in supply \\
Nonmetallic mineral product & $-^{*}$ & $+^{*}$ & Decrease in supply \\
Chemical materials & $-^{*}$ & $+^{*}$ & Decrease in supply \\
Iron and steel products & $-^{*}$ & $+^{*}$ & Decrease in supply \\
Paper & $--^{*}$ & $+^{*}$ & Decrease in supply \\
Plastics and rubber products & $-^{*}$ & $+^{*}$ & Decrease in supply \\
Fabricated metal product & $-^{*}$ & $+^{*}$ & Decrease in supply \\
Automotive products & $-^{*}$ & $+^{*}$ & Decrease in supply \\
Furniture and related product & $-^{*}$ & $+^{*}$ & Decrease in supply \\
Wood product & $-^{*}$ & $-^{*}$ & Decrease in demand \\
Machinery & $-^{*}$ & $+^{*}$ & Decrease in supply \\
Electrical equipment & $-^{*}$ & $+^{*}$ & Decrease in supply \\
\hline
\end{tabular}

Notes: "+" and "-_" represent peak positive and negative responses; "*" means that the peak responses are significant; " 0 " means the peak responses are negligible. "Mixed" means that the positive and negative responses are of similar magnitudes. 


\begin{tabular}{lccc}
\hline \multicolumn{4}{c}{ Oil supply shock } \\
\hline Industry & $\begin{array}{c}\text { Peak effect } \\
\text { on output }\end{array}$ & $\begin{array}{c}\text { Peak effect } \\
\text { on prices }\end{array}$ & Oil supply shock effects \\
\hline Petroleum and coal products & $-^{*}$ & $+^{*}$ & Decrease in supply \\
Ceramic, stone, and clay products & $-*$ & $-*$ & Decrease in demand \\
Nonferrous metals and products & - & - & Decrease in demand \\
Iron and steel products & 0 & $-*$ & \\
Chemicals and related products & - & 0 & Decrease in demand \\
Pulp, paper, and related products & $-^{*}$ & - & Decrease in demand \\
Metal products & $-^{*}$ & - & Decrease in supply \\
Plastic products & $-^{*}$ & $+^{*}$ & \\
General machinery and equipment & 0 & 0 & \\
Precision instruments & $-^{*}$ & 0 & \\
Transportation equipment & 0 & 0 & \\
Electric machinery and equipment & $-^{*}$ & 0 &
\end{tabular}

Global demand shock

\begin{tabular}{lccc}
\hline Industry & $\begin{array}{c}\text { Peak effect } \\
\text { on output }\end{array}$ & $\begin{array}{c}\text { Peak effect } \\
\text { on prices }\end{array}$ & $\begin{array}{c}\text { Global demand shock } \\
\text { effects }\end{array}$ \\
\hline Petroleum and coal products & $+^{*}$ & $+^{*}$ & Increase in demand \\
Ceramic, stone, and clay products & $+^{*}$ & $+^{*}$ & Increase in demand \\
Nonferrous metals and products & $+^{*}$ & $+^{*}$ & Increase in demand \\
Iron and steel products & $+^{*}$ & $+^{*}$ & Increase in demand \\
Chemicals and related products & $+^{*}$ & $+^{*}$ & Increase in demand \\
Pulp, paper, and related products & $+^{*}$ & $+^{*}$ & Increase in demand \\
Metal products & $+^{*}$ & $+^{*}$ & Increase in demand \\
Plastic products & $+^{*}$ & $+^{*}$ & Increase in demand \\
General machinery and equipment & $+^{*}$ & $+^{*}$ & Increase in demand \\
Precision instruments & $+^{*}$ & $-^{*}$ & Increase in supply \\
Transportation equipment & $+^{*}$ & $-{ }^{*}$ & Increase in supply \\
Electric machinery and equipment & $-^{*}$ & - & Increase in demand \\
\hline
\end{tabular}

\begin{tabular}{lccc}
\hline \multicolumn{4}{c}{ Oil-specific demand shock } \\
\hline Industry & $\begin{array}{c}\text { Peak effect } \\
\text { on output }\end{array}$ & $\begin{array}{c}\text { Peak effect } \\
\text { on prices }\end{array}$ & $\begin{array}{c}\text { Oil-specific demand } \\
\text { shock effects }\end{array}$ \\
\hline Petroleum and coal products & Mixed & $+^{*}$ & \\
Ceramic, stone, and clay products & $+^{*}$ & $+^{*}$ & Increase in demand \\
Nonferrous metals and products & Mixed & $+^{*}$ & Increase in demand \\
Iron and steel products & $+^{*}$ & $+^{*}$ & \\
Chemicals and related products & Mixed & $+^{*}$ & \\
Pulp, paper, and related products & Mixed & $+^{*}$ & \\
Metal products & Mixed & $+^{*}$ & Increase in demand \\
Plastic products & Mixed & $+^{*}$ & Increase in demand \\
General machinery and equipment & $+^{*}$ & $+^{*}$ & Increase in demand \\
Precision instruments & $+^{*}$ & $+^{*}$ & \\
Transportation equipment & $+^{*}$ & $+^{*}$ & - \\
Electric machinery and equipment & Mixed & - & \\
\hline
\end{tabular}

Notes: "+" and "_" represent peak positive and negative responses; "*”" means that the peak responses are significant; " 0 " means the peak responses are negligible. "Mixed" means that the positive and negative responses are of similar magnitudes. 

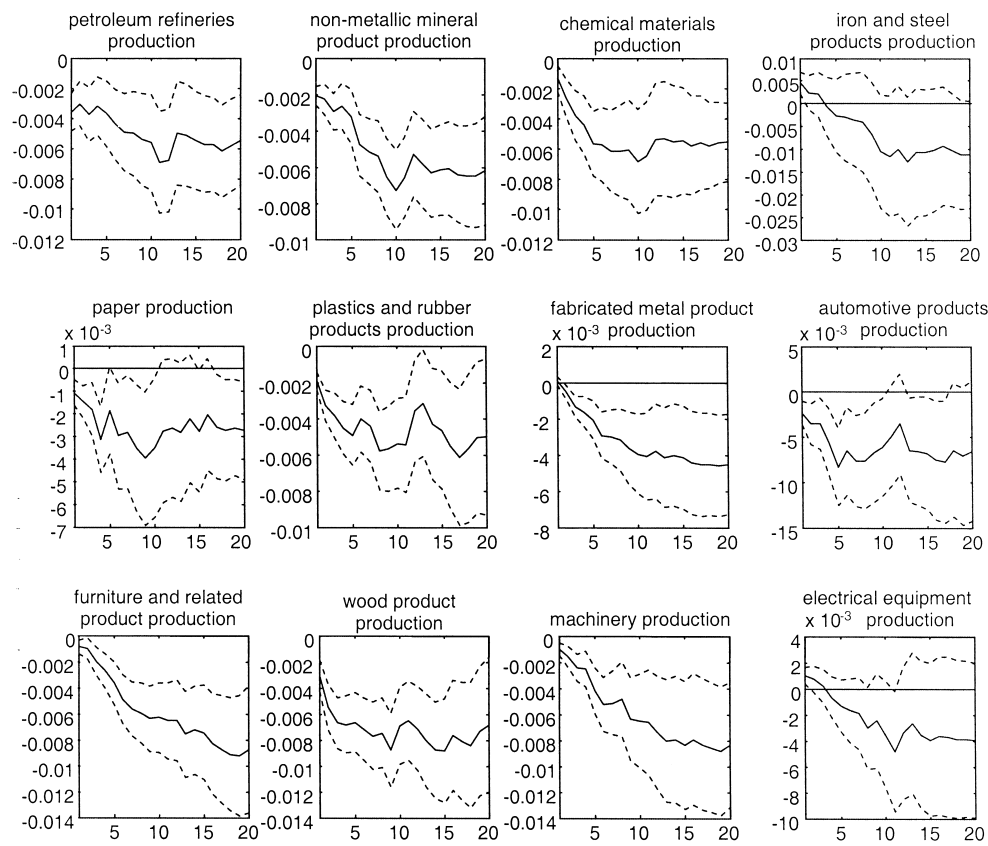

Fig. 6.10 Cumulative responses of production to oil supply shock (U.S.)
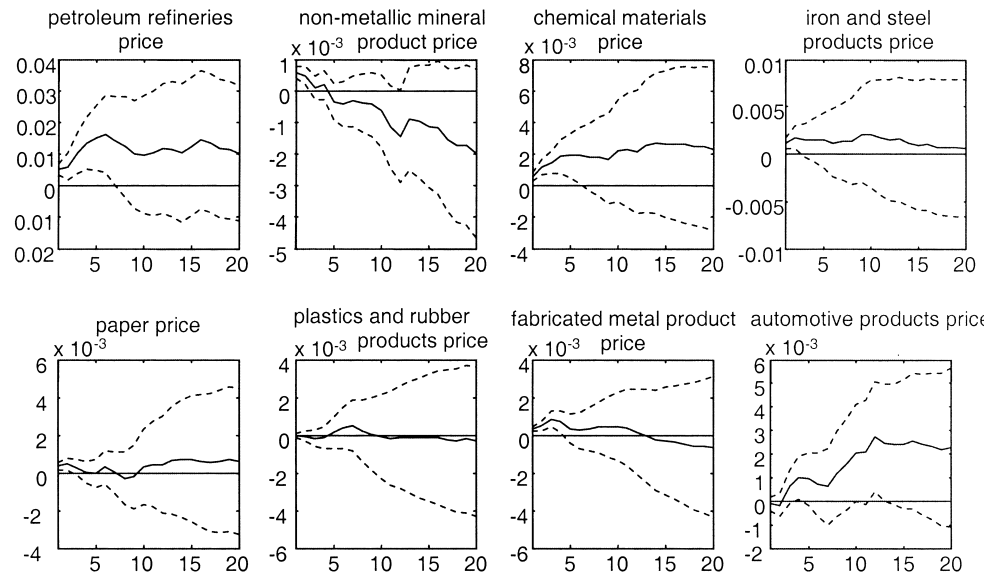

fabricated metal product automotive products price
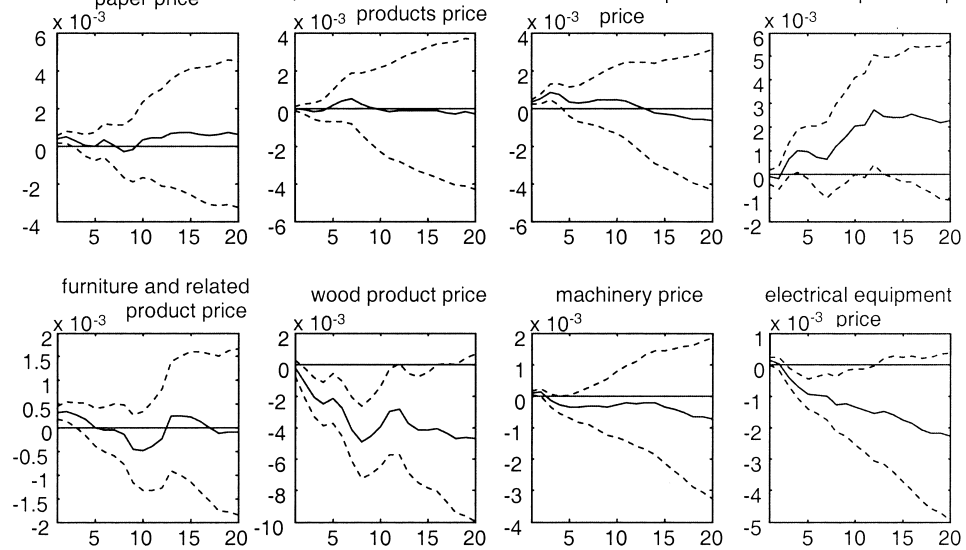

Fig. 6.11 Cumulative responses of prices to oil supply shock (U.S.) 

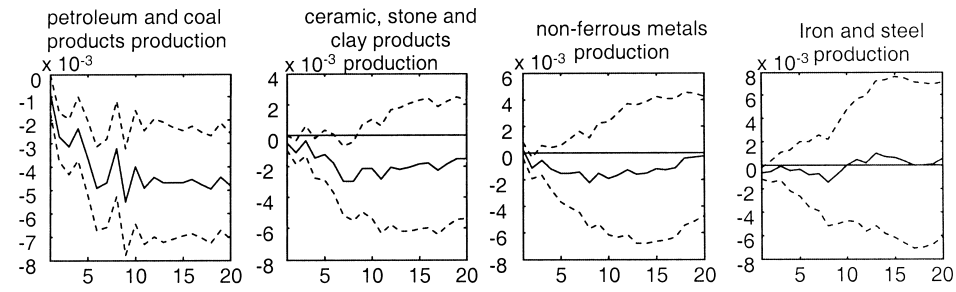

chemicals and related pulp, paper and related products
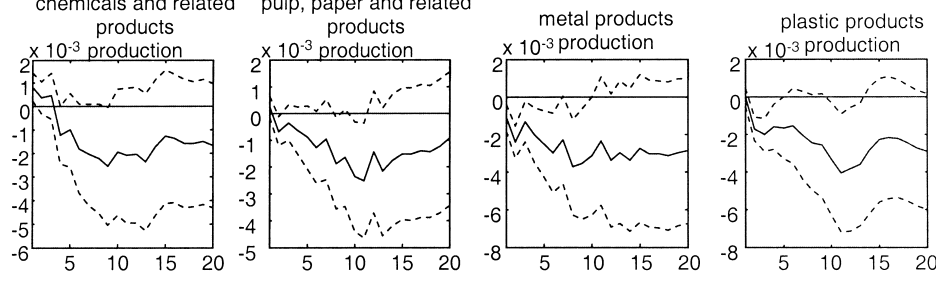

general machinery and equipment
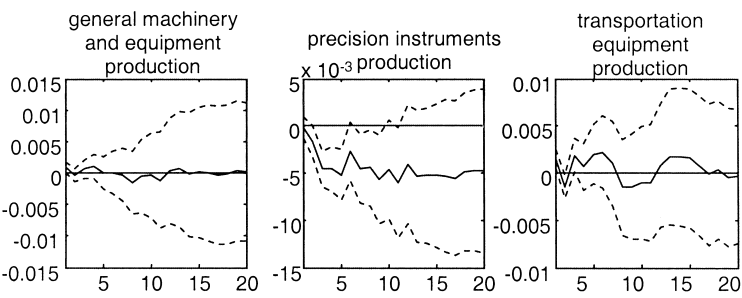

electrical machinery and equipment

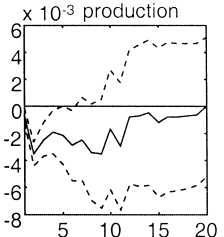

Fig. 6.12 Cumulative responses of production to oil supply shock (Japan)
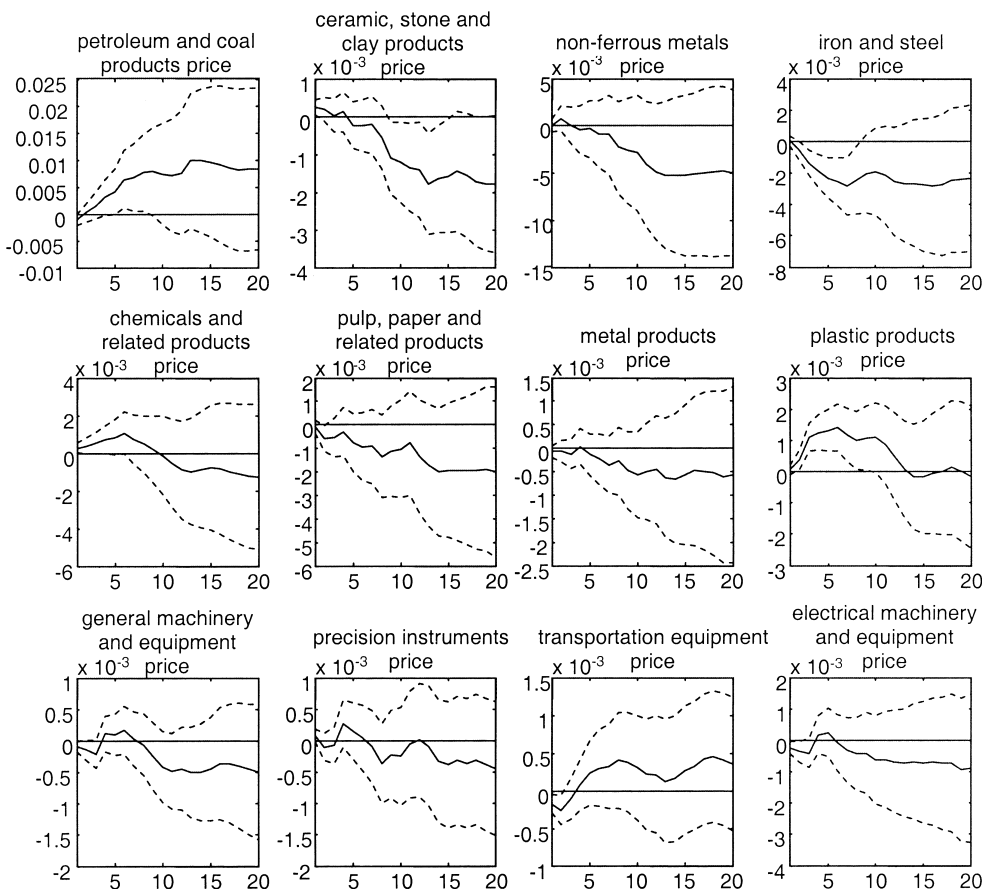

plastic products

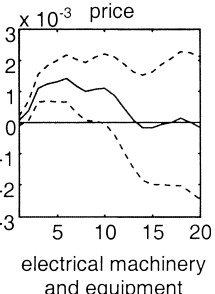

precision instruments

and equipment
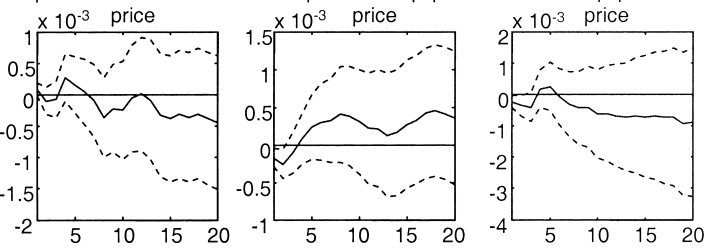

Fig. 6.13 Cumulative responses of prices to oil supply shock (Japan) 
The effects on prices of less oil-intensive industries are mostly statistically insignificant. Overall, the oil supply shocks act mainly as supply shocks for petroleum refineries but have insignificant effects on many other industries in Japan.

\subsubsection{Effects of Global Demand Shocks on Industry-Level Production and Prices}

Figures 6.14 and 6.15 illustrate the responses of production and prices to the global demand shock in the United States. An unexpected expansion in the global demand for all industrial commodities gradually increases the production of most industries. Whereas increases in the production of some export-dependent industries such as machinery and electrical equipment last for about a year, the increases in many other industries last for only a few months or half a year. In particular, automotive products, furniture and related product, wood product, and some oil-intensive industries including petroleum refineries, experience only transitory increases in production. At the same time, a positive global demand shock gradually and persistently increases the prices of most industries. The price increase in petroleum refineries is the largest among the industries. Prices in many less oil-intensive industries also increase, but by less than do those in oil-intensive industries. These results imply that the global demand shocks act mainly as demand shocks, at least in the short run, for most industries. Note that these global demand shocks act as positive demand shocks for many industries, in contrast to the oil supply shocks, which act as negative demand shocks for less oil-intensive industries.

The responses of production and prices to the same shock in Japan are shown in figures 6.16 and 6.17. As in the United States, a positive global demand shock gradually increases production of most industries in Japan. Whereas the increases in production of some oil-intensive industries such as petroleum and coal products last for only about half a year, production increases in many less oil-intensive and export-dependent industries last for about a year, and the effects are larger than those in oil-intensive industries. Compared with the United States, the global demand shocks have persistent effects on production in a wider range of industries, which include transportation equipment. At the same time, a positive global demand shock gradually and persistently raises the prices of many industries, particularly oil-intensive industries. By contrast, prices of some less oil-intensive industries such as precision instruments and transportation equipment fall, at least in the short run. As in the United States, the global demand shocks act mainly as demand shocks for most industries in Japan. However, the magnitude and persistence of the effects in some industries differ greatly from the corresponding effects in the United States. 

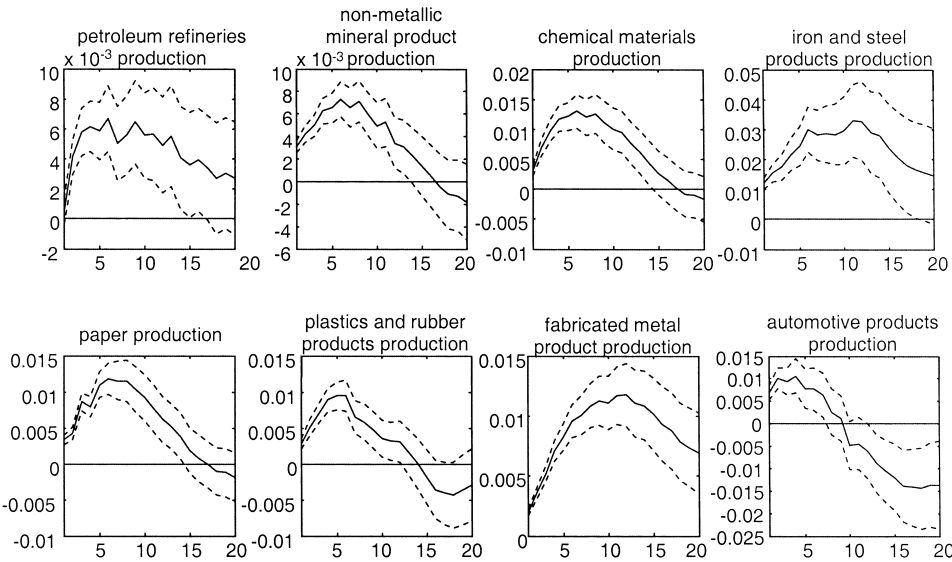

automotive products
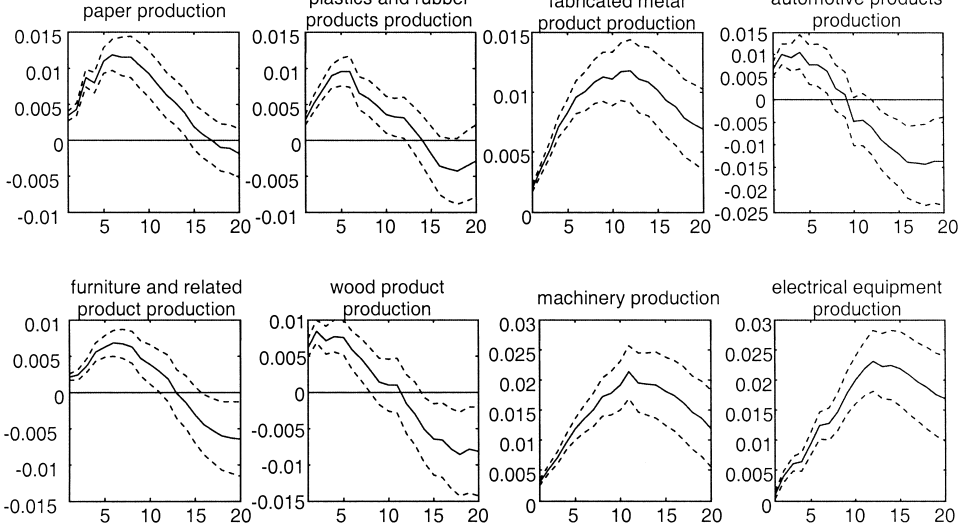

Fig. 6.14 Cumulative responses of production to global demand shock (U.S.)
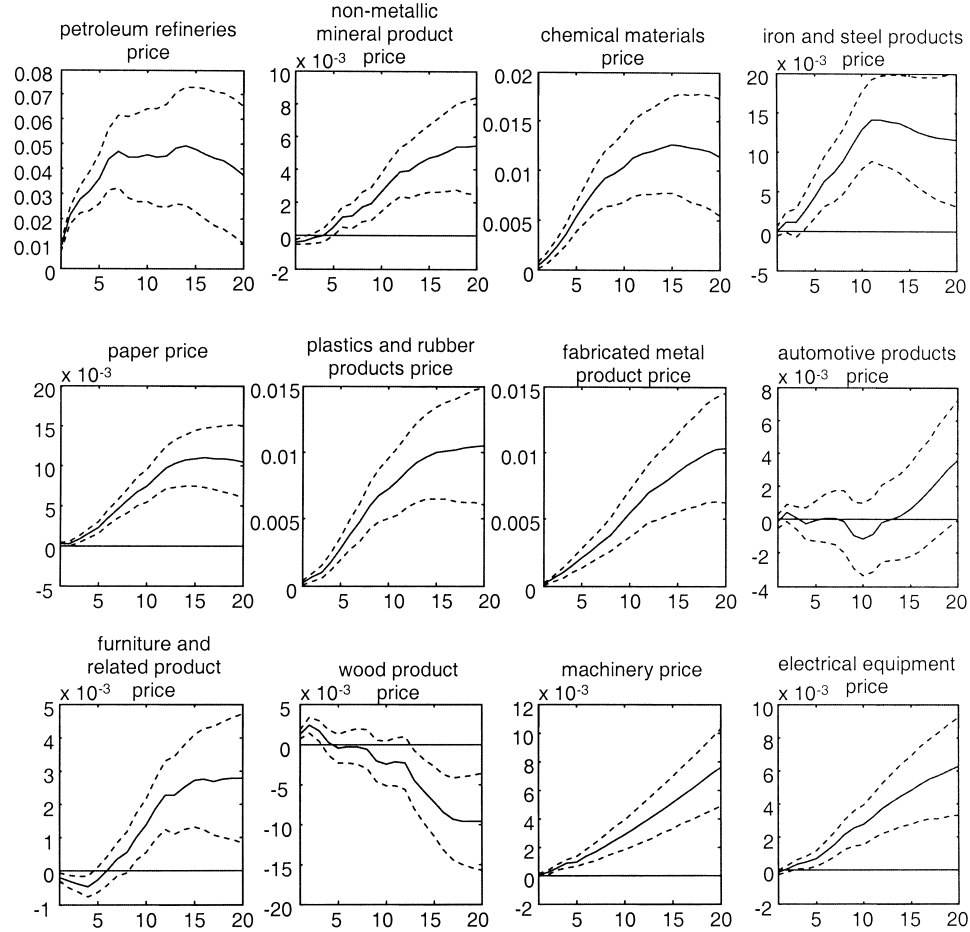

electrical equipment

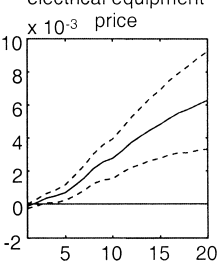

Fig. 6.15 Cumulative responses of prices to global demand shock (U.S.) 

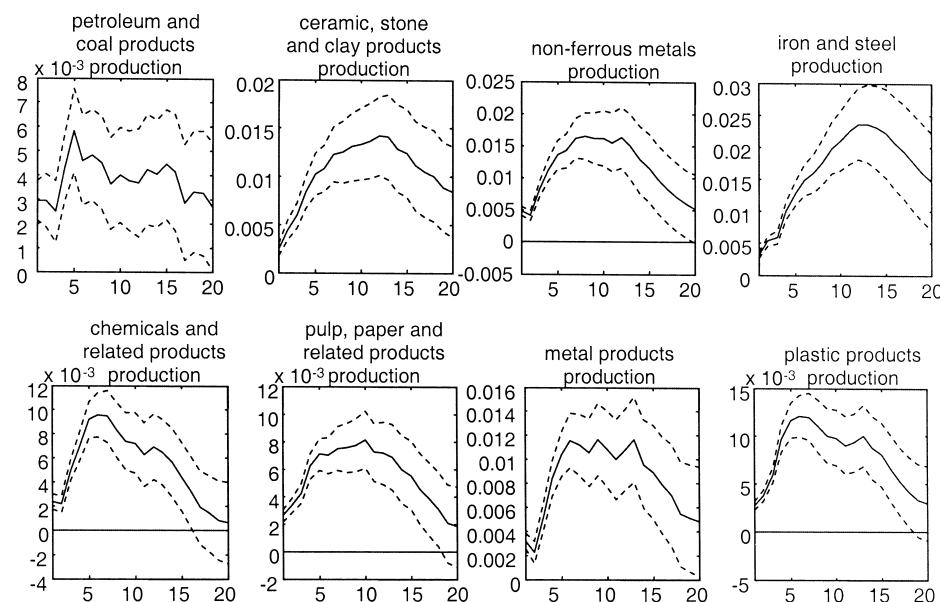

pulp, paper and

related products

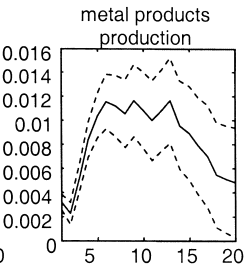

plastic products
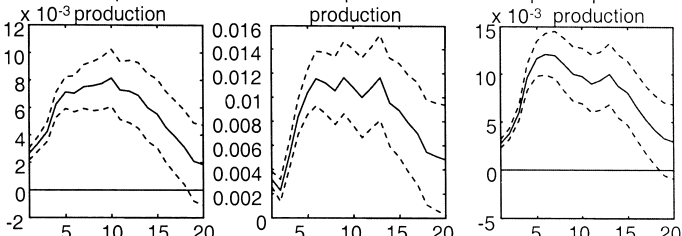

general machinery
and equipment
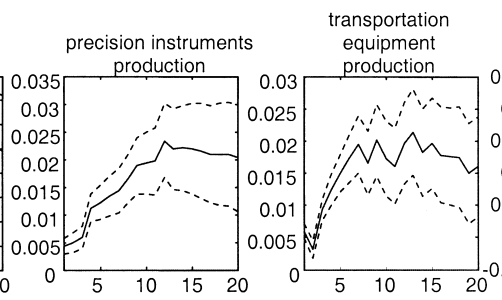

electrical machinery and equipment
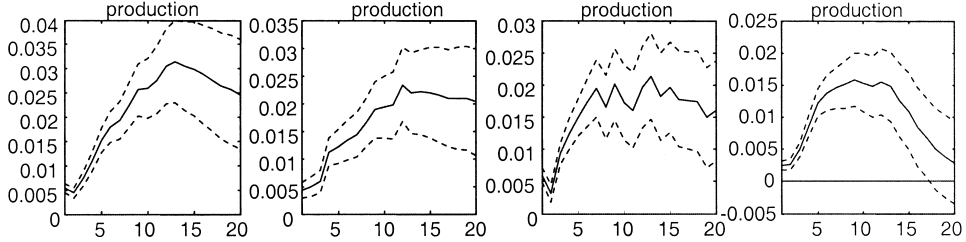

Fig. 6.16 Cumulative responses of production to global demand shock (Japan)
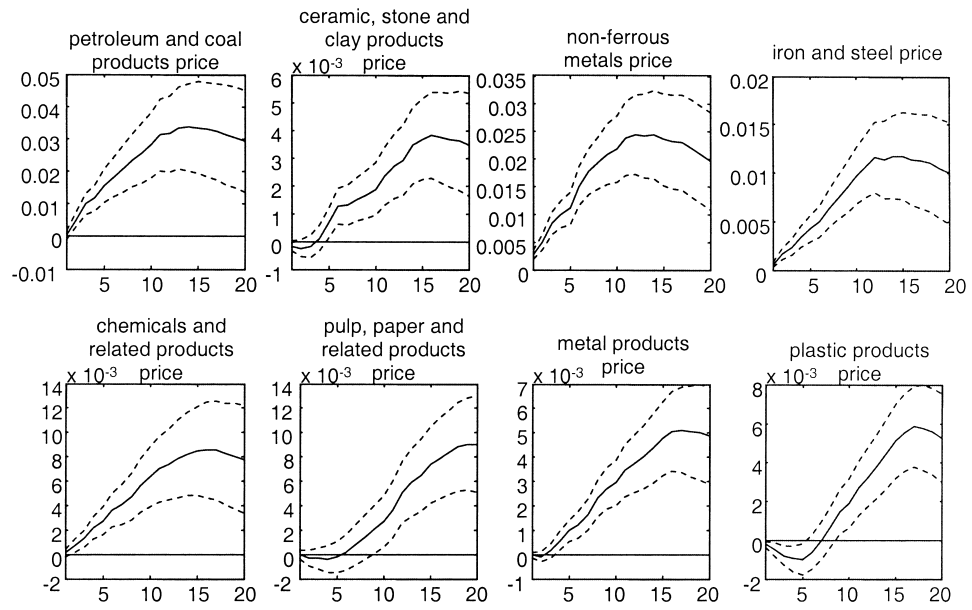

plastic products
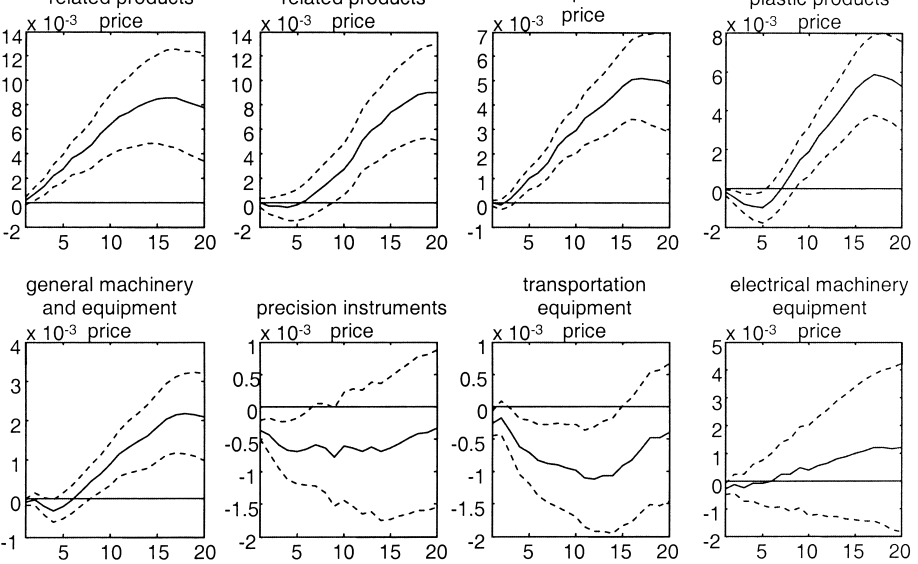

electrical machinery equipment
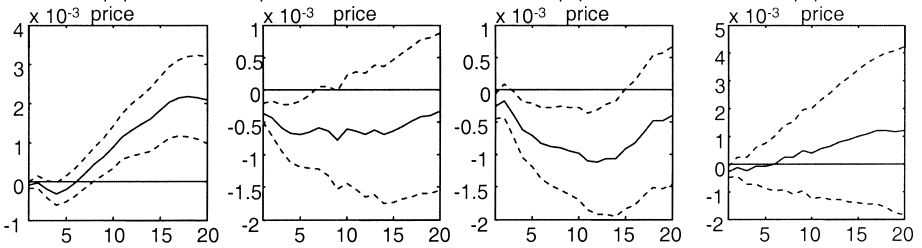

Fig. 6.17 Cumulative responses of prices to global demand shock (Japan) 


\subsubsection{Effects of Oil-Specific Demand Shocks on Industry-Level Production and Prices}

Figures 6.18 and 6.19 illustrate the responses of production and prices to the oil-specific demand shock in the United States. An unexpected increase in demand that is specific to the global oil market gradually and persistently reduces the production of most industries, with a half-year lag. The decrease in automotive production is the largest, and generally production declines are relatively large in less oil-intensive industries. At the same time, a positive oil-specific demand shock persistently increases the prices of most industries. In petroleum refineries, prices increase on impact and then continue to rise until around a year after the shock, which is the largest increase among the industries. Prices in many less oil-intensive industries, including automotive products, also increase, but generally by less than those in oil-intensive industries. These results imply that the oil-specific demand shocks act mainly as supply shocks for most industries.

Lastly, the responses of production and prices to the same shock in Japan are shown in figures 6.20 and 6.21. Of the three structural shocks, the responses to the oil-specific demand shock differ most between the United States and Japan. Unlike in the United States, a positive oil-specific demand shock raises rather than reduces production of most industries in Japan, at least in the short run. Whereas production increases in oil-intensive industries are small and transitory, those in some less oil-intensive and exportdependent industries, such as general machinery, precision instruments, and transportation equipment, last for about a year. Therefore, the oil-specific demand shocks have similar effects on production to the global demand shocks, although the latter have much larger effects. At the same time, a positive oil-specific demand shock gradually and persistently raises the prices of most industries. Unlike in the United States, the oil-specific demand shocks act mainly as demand shocks rather than supply shocks for many industries in Japan.

\subsection{Discussion}

The estimation results for the domestic industry block in section 6.4 reveal that whether the oil price changes act as supply shocks or demand shocks for each industry depends on what kind of underlying shock drives the oil price changes. It also depends on each industry's characteristics: that is, oil price changes tend to act more as supply shocks for oil-intensive industries and tend to act more as demand shocks for less oil-intensive industries, as shown by Lee and $\mathrm{Ni}$ (2002). However, our results imply that the global demand shocks act mainly as demand shocks for most industries, including oil-intensive industries, and that the oil-specific demand shocks act mainly as supply shocks for most industries, including less oil-intensive industries in the United States. Considering this key finding, we briefly survey the 

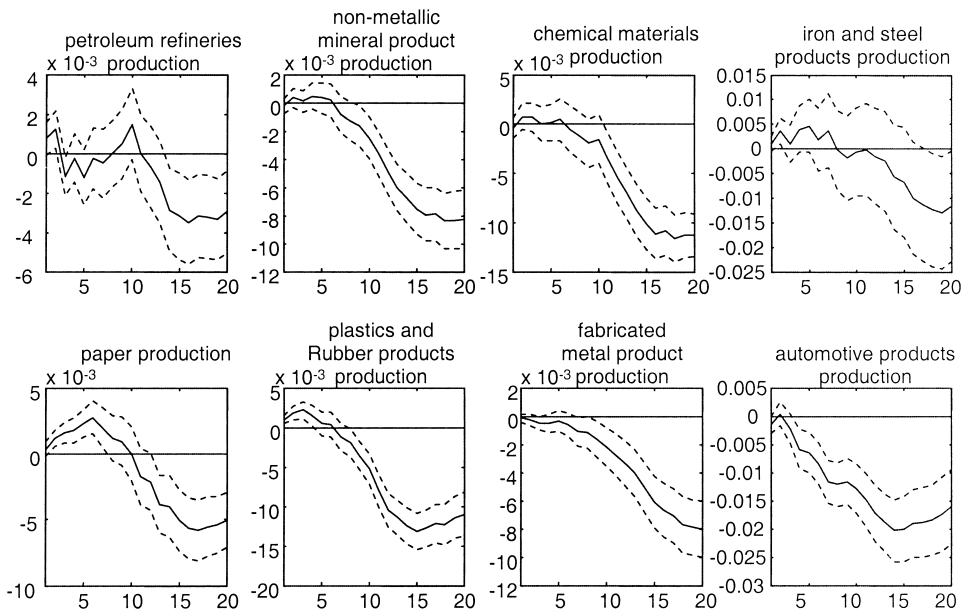

automotive products
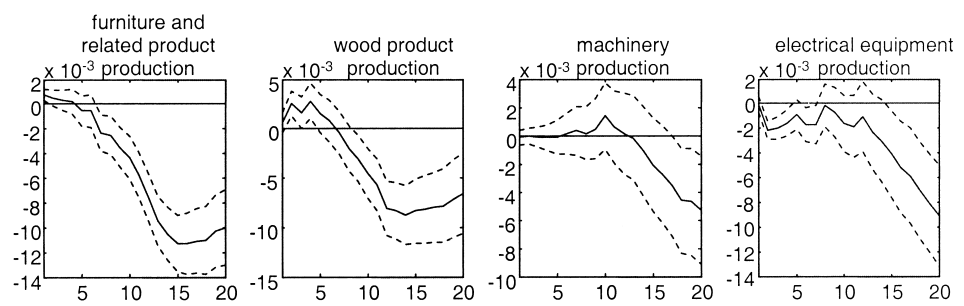

Fig. 6.18 Cumulative responses of production to oil-specific demand shock (U.S.)
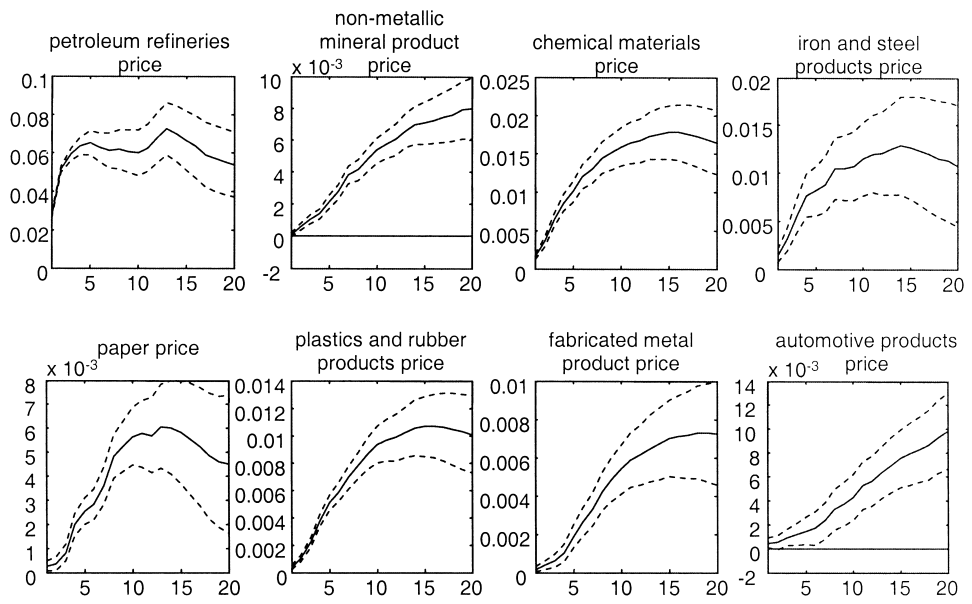

plastics and rubber

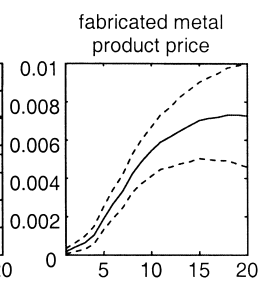

automotive products

products price

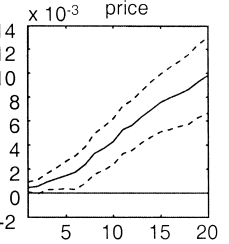

rniture and

related product

wood product
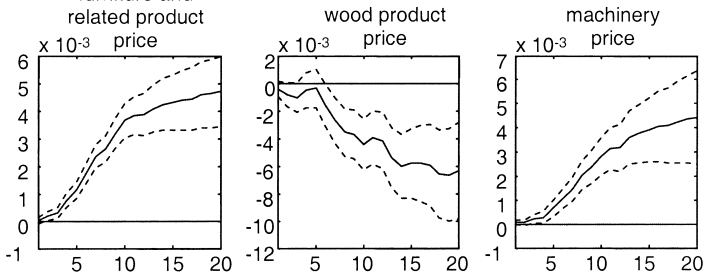

electrical equipment

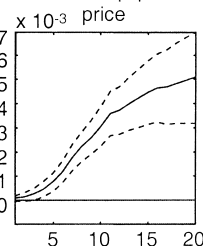

Fig. 6.19 Cumulative responses of prices to oil-specific demand shock (U.S.) 


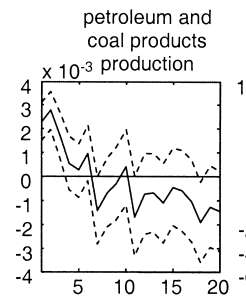

ceramic, stone

and clay products

non-ferrous metals

iron and steel
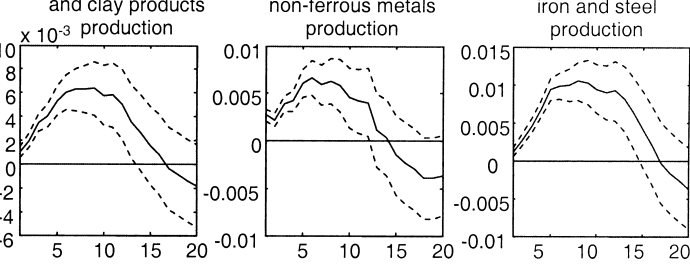

chemicals and

related products

ulp, paper and

related products

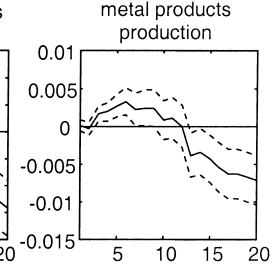

plastic products $\times 10^{-3}$ production
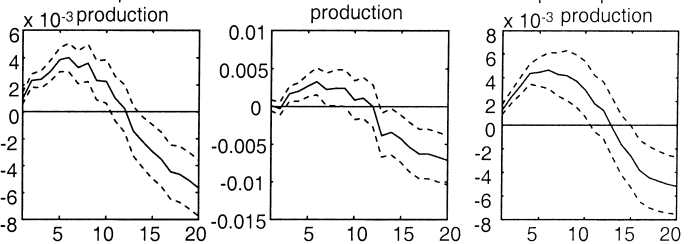

general machinery and equipment

precision instruments

transportation equipment electrical machinery production
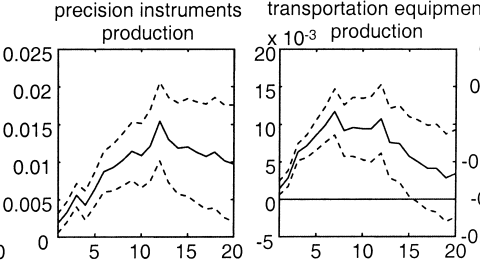

and equipment
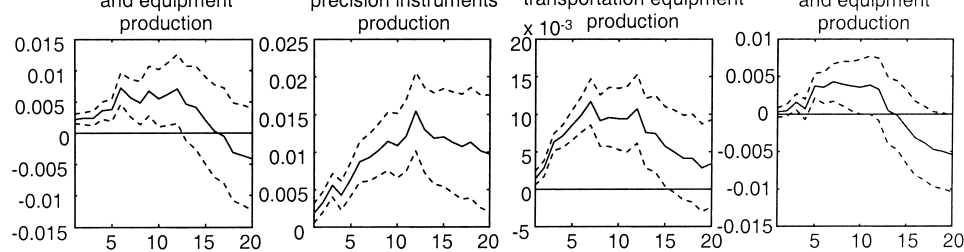

Fig. 6.20 Cumulative responses of production to oil-specific demand shock (Japan)
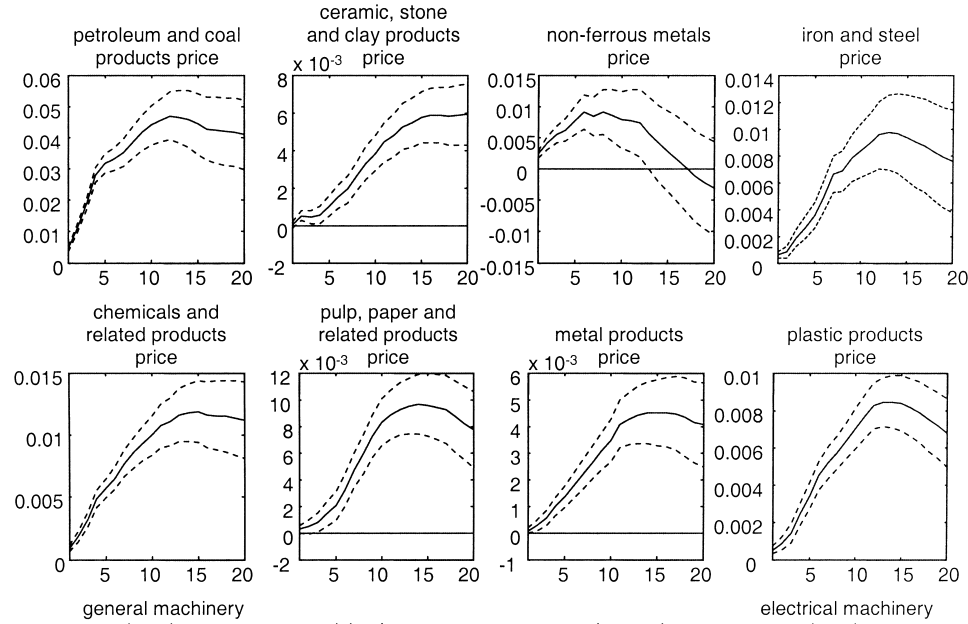

and equipment

precision instruments
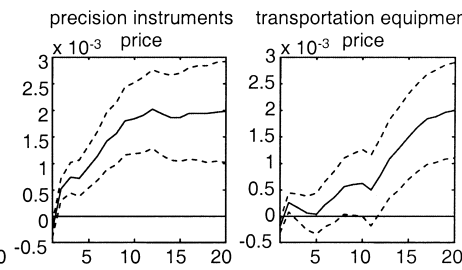

electrical machinery and equipment
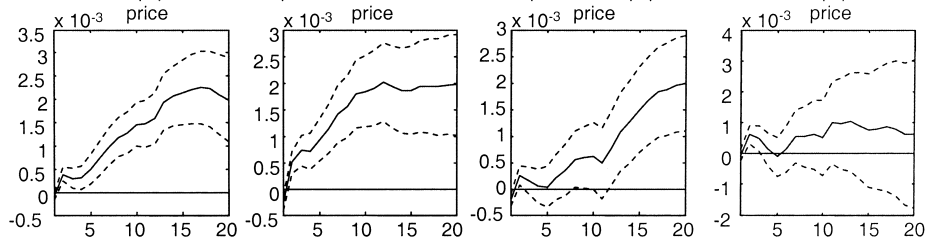

Fig. 6.21 Cumulative responses of prices to oil-specific demand shock (Japan) 
transmission mechanisms of oil price changes and interpret our estimation results in more detail. The three structural shocks to the global oil market identified in our model are transmitted to each industry through various channels, some of which are familiar and others less familiar in the literature. ${ }^{20}$

Another key finding is that the transmission mechanisms differ considerably between the United States and Japan. In particular, the oil-specific demand shocks in Japan act mainly as demand shocks rather than supply shocks for many industries. Following discussion of the transmission mechanisms, we consider the background of the differences between the United States and Japan.

\subsubsection{Transmission Mechanisms of Oil Price Changes}

Oil price changes have been viewed traditionally as cost shocks or productivity shocks to oil-importing countries, and many studies focus on the supply side of their transmission mechanisms. ${ }^{21}$ When an oil price hike pushes up production costs, producers reduce their use of oil, which may lower the productivity of capital and labor. This cost channel or supply channel of transmission operates mainly in oil-intensive industries. According to our estimation results, the magnitudes of the price responses to any kind of structural shock to the global oil market are relatively large in oilintensive industries, particularly petroleum refineries. However, production responses in oil-intensive industries are not particularly large. The effect of an oil-specific demand shock in the United States on production of oilintensive industries is smaller than that of less oil-intensive industries such as automotive products. The production of oil-intensive industries increases rather than decreases in response to a positive global demand shock, which moves in the same direction as prices. Because the economy-wide cost share of oil is low, it is reasonable to suppose that the direct effect of the cost channel by itself cannot explain the whole impact of oil price changes on economic activity. ${ }^{22}$

Another important channel of the transmission is on the demand side of the economy. Kilian (2008) categorizes the effects of oil price changes on consumption expenditure into a discretionary income effect, a precautionary savings effect, an uncertainty effect, and an operating cost effect. ${ }^{23}$ The

20. The survey is limited to mechanisms relating to our estimation results. Because our models do not explicitly consider either monetary policy shocks or endogenous responses of monetary policy to oil price changes, we ignore the relationship between oil prices and monetary policy.

21. For instance, Bruno and Sachs (1985) extensively study the supply side of the transmission mechanisms of oil price changes.

22. Hamilton (2008) discusses the empirical relevance of the cost channel in his survey of the mechanisms through which the effects of oil price changes are transmitted to the macroeconomy.

23. Oil price changes also affect firms' investment expenditures, but these effects are considered small by Kilian (2008). 
first two effects, which operate through consumers' present and expected future incomes, relate to a wide range of goods and services, whereas the other two effects relate only to consumer durables. The uncertainty effect of oil price changes causes consumers to postpone irreversible purchases of consumer durables, and the operating cost effect causes consumers to refrain from purchasing oil-using durables, particularly automobiles. According to our estimation results, the U.S. automotive industry exhibits the largest production decrease following a positive oil-specific demand shock. This implies that the oil-specific demand shocks act as demand shocks as well as supply shocks for the U.S. automotive industry, though the negative effect on prices through the demand channel is not as strong as the positive effect on prices through the supply channel. Note that all the aforementioned effects of oil price increases reduce consumption expenditure; that is, they act as negative demand shocks. By contrast, the global demand shocks identified in our model act mainly as positive demand shocks. This is because, by construction, these shocks incorporate positive shocks to the income of U.S. or other countries' residents who purchase U.S. products. More precisely, however, the global demand shocks act as both positive and negative demand shocks that offset each other: the positive effects operate through positive income shocks and the negative effects operate through the oil price increases induced by the same shocks. According to our estimation results, a positive global demand shock raises U.S. automotive production only slightly and temporarily, relative to other less oil-intensive industries such as machinery and electrical equipment. This is because the negative effect that operates through the oil price increase in the automotive industry is stronger than in other less oil-intensive industries.

If oil price changes intensively affect a certain sector of the economy, whether through the supply or demand channel, sectoral shifts of resources between the affected sector and less affected sectors are likely to occur. In the process of such sectoral shifts, some resources might be unemployed by any sector because of frictions in capital and labor markets, which may further depress aggregate economic activity and amplify the negative effects of oil price changes. This reallocation effect has been discussed by many researchers, including Hamilton (1988) and Davis and Haltiwanger (2001). Our estimation results, however, do not provide clear evidence of significant resource reallocation across industries either for the United States or Japan. Although the magnitudes of the production responses to each type of shocks differ considerably across industries, the directions of the responses are the same for most industries.

Meanwhile, some of our results imply demand shifts across countries. The production increases in export-dependent industries, such as machinery and electric equipment, that follow a positive global demand shock tend to be larger and more persistent than those of less export-dependent industries, both in the United States and Japan. This is because, as mentioned before, 
the global demand shocks partly reflect changes in the incomes of foreign residents who purchase domestic products. Moreover, demand shifts from U.S. products to Japanese products might constitute an explanation for the significant difference in the effects of the oil-specific demand shocks between the two countries, as discussed in the next subsection. These global transmission channels of oil price changes have received relatively less attention in the literature. ${ }^{24}$

\subsubsection{Differences between the United States and Japan}

Based on the previous discussion, we consider the background of the differences between our estimation results for the United States and Japan. For Japan, in many industries, the production responses to the oil supply shock are weaker or statistically insignificant, and those to the global demand shock are stronger than those of the United States. These differences are explained by the fact that Japan's economy is less oil-intensive and more export-dependent than the United States, as shown in section 6.4.1.

The biggest difference is in the effects of the oil-specific demand shocks. For many industries in Japan, production as well as prices increase rather than decrease in response to a positive oil-specific demand shock. Therefore, the oil-specific demand shocks act mainly as positive demand shocks, similarly to the global demand shocks. This implies the existence of some oil-specific factors, which cannot be explained by the global demand shocks, causing global demand shifts toward Japanese products. One possibility is the oil efficiency of Japanese products. In particular, Japanese automotive manufacturers have produced smaller and more oil-efficient cars than have U.S. manufacturers since the 1970s. By causing a massive demand shift toward small cars, the oil crisis of the 1970s damaged U.S. carmakers, who produced only large cars, as documented by Bresnahan and Ramey (1993), among others. At the same time, Japanese carmakers sharply raised their market shares in the United States. ${ }^{25}$ These demand shifts have continued until recently. Figure 6.22 shows that the market share of Japanese cars in the United States started rising again when gasoline prices increased around 1999. In 2004 to 2006, Japanese cars were still more fuel efficient than U.S. cars, as shown in figure 6.23. These demand shifts might constitute an explanation for why U.S. and Japanese automotive production differ in their responses to the oil-specific demand shocks; among our selected industries, automotive production differs the most between the United States and

24. Some large-scale multicountry macroeconomic models, including "G-Cubed model" (McKibbin and Wilcoxen 1998) and the International Monetary Fund's (IMF's) "Global Economy Model (GEM)" (Pesenti 2008), consider the global transmission channels of oil price changes.

25. There are many empirical studies on the U.S. automobile market. For instance, Goldberg (1998) examines the effects of the Corporate Average Fuel Economy Standards enacted in 1975 on automobile sales, prices, and fuel consumption, considering demand shifts toward more fuel-efficient vehicles. 


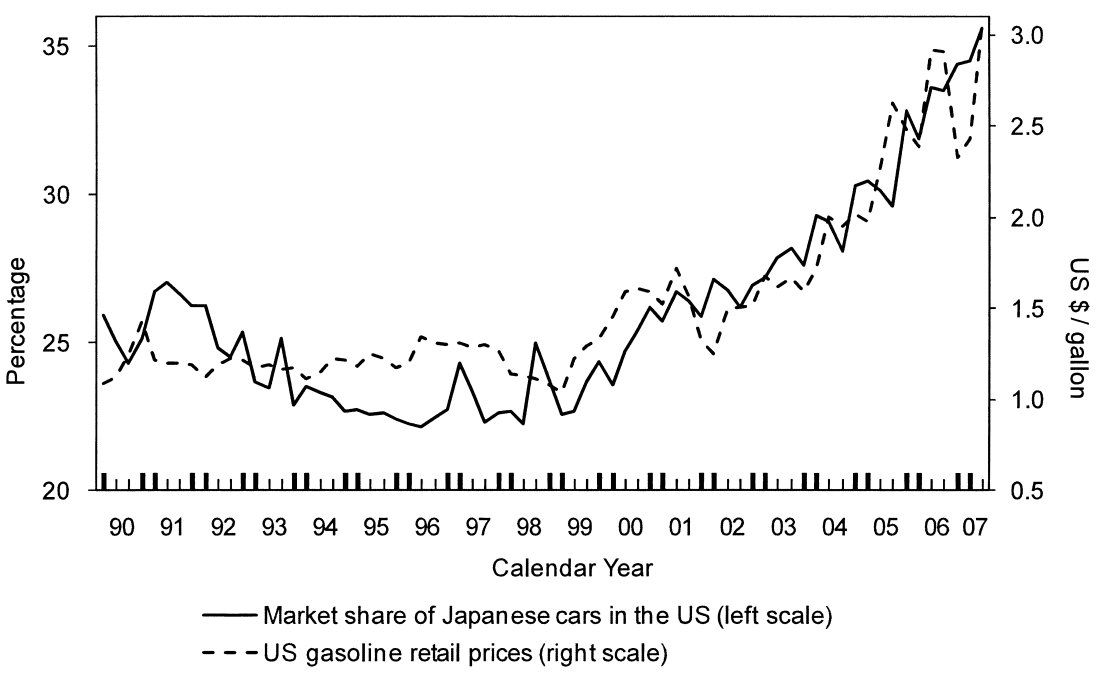

Fig. 6.22 Market share of Japanese cars in United States

Source: Research and Statistics Department, Bank of Japan (2007).

Japan. Moreover, the demand for automotive products induces production of many other industries such as steel and precision instruments. Although the value-added share of passenger cars (excluding buses and trucks) in Japanese industrial production is only about 8.5 percent, the economy-wide impacts of demand shifts toward Japanese cars may be substantial.

\subsection{Concluding Remarks}

In this chapter, we decomposed oil price changes into their component parts following Kilian (2009) and estimated the dynamic effects of each component on industry-level production and prices in the United States and Japan using identified VAR models. Our results reveal that the way oil price changes affect each industry depends on what kind of underlying shock drives the oil price changes as well as on industry characteristics. We also found that the transmission mechanisms differ considerably between the United States and Japan.

Our results imply that global demand shifts across countries are important factors for oil price changes themselves and their transmission mechanisms. We considered the global demand shocks as underlying causes of oil price changes and discussed the effects of global demand shifts toward more oil-efficient products. For a better understanding of the transmission mechanisms, it would be worth investigating differences in the effects of oil price changes among countries other than the United States and Japan. Moreover, developing open-economy dynamic stochastic general equilibrium models 


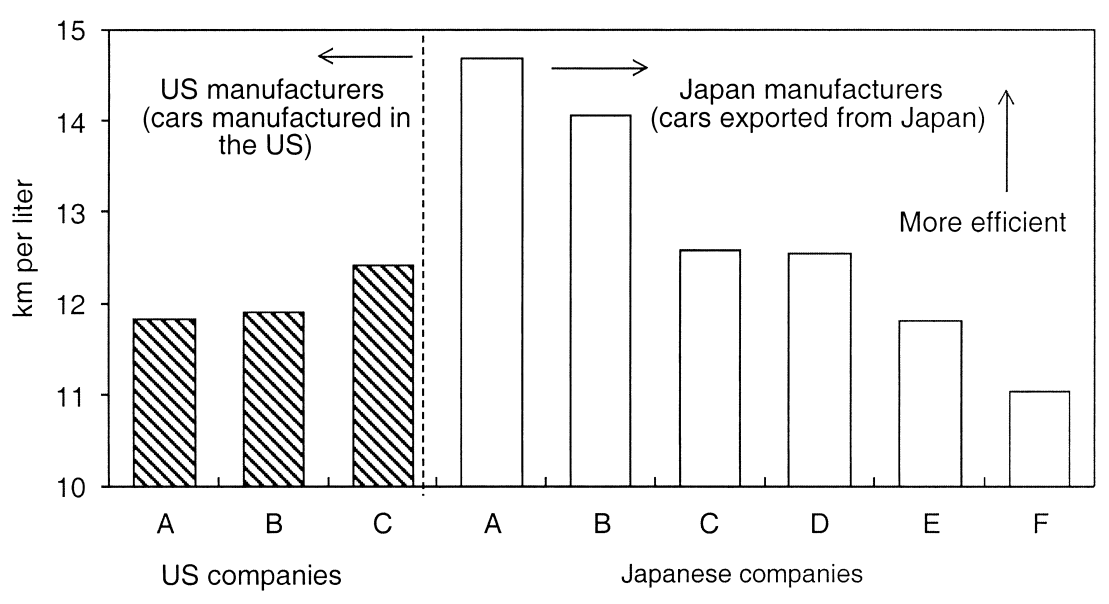

Fig. 6.23 Average fuel consumption of cars sold in United States

Source: Research and Statistics Department, Bank of Japan (2007).

Notes: Fuel consumption is calculated for each company as 2004 to 2006 averages. Fuel consumption of different vehicle types are averaged using their sales volume as weights.

that incorporate the global oil market is also a promising way of deepening our understanding and would enhance the interpretation of empirical results on the effects of oil price changes.

\section{Appendix}

\section{Robustness Checks}

In this appendix, we summarize the estimation results under several alternative assumptions and specifications of the model to check the robustness of our main results. ${ }^{26}$

First, we changed the sample period of estimation, while keeping the model unchanged. Although we focus on changes in the nature of the shocks rather than structural changes as an explanation for the weakening effects of oil price changes on real economic activity (as stated in footnote 5), it is possible to estimate our models for shorter sample periods and check whether structural changes occurred during the full sample period. We divided the sample period into the two subperiods, 1973:1 to $1983: 12$ and 1984:1 to 2008:12, following Blanchard and Galí (2007) in choosing the break point. In the later subperiod, the negative effects of the oil supply shocks on pro-

26. The detailed results of the robustness checks will be available upon request. 
duction were weakened in both the United States and Japan, the positive effects of the global demand shocks on production were strengthened in Japan, and the effects of the oil-specific demand shocks were little changed in both countries. Therefore, structural changes occurred only in the effects of oil price changes caused by the oil supply shocks (and the global demand shocks in Japan), which historically made a small contribution to oil price movements (as shown in figure 6.3). Overall, the directions of the responses to the three structural shocks were little changed in each industry.

Second, we partially relaxed the block recursive restrictions and assumed that domestic aggregate variables could affect global oil market variables. Third, we included in the domestic macroeconomy block the short-term nominal interest rate and the real effective exchange rate in addition to aggregate industrial production..$^{27}$ Lastly, we changed the ordering of the variables in the domestic industry block (industrial production and producer prices) so that prices rather than production come first. We found that all these changes made little differences to our main results.

\section{References}

Blanchard, O. J., and J. Galí. 2007. The macroeconomic effects of oil shocks: Why are the 2000s so different from the 1970s? NBER Working Paper no. 13368. Cambridge, MA: National Bureau of Economic Research, September.

Bresnahan, T. F., and V. A. Ramey. 1993. Segment shifts and capacity utilization in the U.S. automobile industry. American Economic Review 83 (2): 213-18.

Bruno, M., and J. Sachs. 1985. Economics of worldwide stagflation. Cambridge, MA: Harvard University Press.

Davis, S. J., and J. Haltiwanger. 2001. Sectoral job creation and destruction responses to oil price changes. Journal of Monetary Economics 48 (3): 465-512.

Goldberg, P. K. 1998. The effects of the corporate average fuel efficiency standards in the U.S. Journal of Industrial Economics 46 (1): 1-33.

Hamilton, J. D. 1988. A neoclassical model of unemployment and the business cycle. Journal of Political Economy 96 (3): 593-617.

1996. This is what happened to the oil price-macroeconomy relationship. Journal of Monetary Economics 38 (2): 215-20.

2008. Oil and the macroeconomy. In The new Palgrave dictionary of economics, 2nd ed., ed. S. N. Durlauf and L. E. Blume. Houndmills, UK: Palgrave Macmillan.

Hirakata, N., and N. Sudo. 2009. Accounting for oil price variation and weakening impact of the oil crisis. IMES Discussion Paper no. 2009-E-1. Institute for Monetary and Economic Studies, Bank of Japan.

Hooker, M. A. 1996. This is what happened to the oil price-macroeconomy relationship: Reply. Journal of Monetary Economics 38 (2): 221-2.

27. The short-term nominal interest rate we use is the federal funds rate for the United States and overnight call rate for Japan. We use the real effective exchange rates published by the Federal Reserve Board and those published by Bank of Japan. 
Jiménez-Rodríguez, R., and M. Sánchez. 2004. Oil price shocks and real GDP growth: Empirical evidence for some OECD countries. ECB Working Paper no. 362. European Central Bank, Frankfurt am Main.

Kilian, L. 2008. The economic effects of energy price shocks. Journal of Economic Literature 46 (4): 871-909.

2009. Not all oil price shocks are alike: Disentangling demand and supply shocks in the crude oil market. American Economic Review 99 (3): 1053-69.

Kilian, L., and C. Park. 2009. The impact of oil price shocks on the U.S. stock market. International Economic Review 50 (4): 1267-87.

Lee, K., and S. Ni. 2002. On the dynamic effects of oil price shocks: A study using industry level data. Journal of Monetary Economics 49 (4): 823-52.

McKibbin, W., and P. Wilcoxen. 1998. The theoretical and empirical structure of the G-Cubed model. Economic Modelling 16 (1): 123-48.

Pesenti, P. 2008. The global economy model: Theoretical framework. IMF Staff Papers 55 (2): 243-84.

Research and Statistics Department, Bank of Japan. 2007. Recent developments of Japan's external trade and corporate behavior. BOJ Reports \& Research Papers (Ad Hoc Themes). Bank of Japan.

Rotemberg, J. J., and M. Woodford. 1996. Imperfect competition and the effects of energy price increases on economic activity. Journal of Money, Credit, and Banking 28 (4): 549-77.

\section{Comment Francis T. Lui}

Fukunaga, Hirakata, and Sudo's chapter provides a useful analysis of how shocks in oil prices affect production and prices at industry and aggregate economy levels. Changes in oil prices have been regarded in the real business cycles (RBC) literature as a major source of productivity shocks that can cause business cycles. The findings of this chapter therefore may have interesting implications for RBC models. They also remind us that the particular transmission mechanism of the effects of oil price changes matters a lot and that different economies may respond to these shocks in different ways.

The methodology of the chapter consists of using an identified VAR model with three sets of variables. They are

$X_{1 t}=$ global oil market variables

$=$ (world crude oil output, world industrial output, spot crude oil price)

$X_{2 t}=$ domestic aggregate variable

$=$ (aggregate industrial production)

$X_{3 t}=$ domestic industry-level variables

= industry production, producer price)

Francis T. Lui is a professor of economics at the Hong Kong University of Science and Technology. 